\title{
ODREĐIVANJE MJESNE NADLEŽNOSTI OD STRANE VIŠIH SUDOVA U PARNIČNOM POSTUPKU U POJEDINIM PREDMETIMA
}

Dr. sc. Mihajlo Dika, prof. emer.*

\author{
UDK 347.91/.95(497.5) \\ https://doi.org/10.30925/zpfsr.39.1.1 \\ Ur.: 1. ožujka 2018. \\ Pr.: 6. ožujka 2018. \\ Izvorni znanstveni rad
}

\begin{abstract}
Sažetak
Predmet rada su tri instituta kojima se uređuje određivanje mjesne nadležnosti od strane viših sudova u parničnom postupku u pojedinim predmetima-institut tzv. nužne delegacije nadležnosti, institut tzv. svrhovite delegacije nadležnosti te institut tzv. ordinacije nadležnosti. Prigodom obrade svakog od navedenih instituta nastoji se odrediti njihov pojam, pretpostavke i pravni učinci njihove primjene. Nastoji se upozoriti i na mogućnost njihove funkcionalne interferencije te potrebu razgraničenja u primjeni. Posebno je istaknut utjecaj relativno recentnih intervencija u uređenje organizacije sudova i njihove nadležnosti na njihovo praktično značenje.
\end{abstract}

Ključne riječi: mjesna nadležnost, nužna delegacija mjesne nadležnosti, svrhovita delegacija mjesne nadležnosti, ordinacija mjesne nadležnosti

\section{1. $U V O D$}

U parničnom postupku viši sudovi mogu doći u prigodu da u pojedinim pravnim stvarima određuju mjesnu nadležnost na dva načina: prvo, prenošenjem te nadležnosti sa suda koji je po zakonu tako nadležan na drugi stvarno nadležni sud te, drugo, određivanjem koji će od stvarno nadležnih sudova biti nadležan u slučajevima u kojima postoji jurisdikcija hrvatskih sudova, ali se, na temelju važećih pravila o mjesnoj nadležnosti, ne može utvrditi koji je sud mjesno nadležan. Na prvi naznačeni način mjesna se nadležnost nižih sudova delegira u slučajevima u kojima su ispunjeni uvjeti za tzv. nužnu (67.) $)^{1}$ i za tzv. svrhovitu delegaciju (68.) takve nadležnosti,

* Dr. sc. Mihajlo Dika, professor emeritus Pravnog fakulteta u Zagrebu.

1 U ovom radu odredbe pojedinih zakona označavat će se navođenjem broja članka, stavka, odvojenog kosom crtom od broja članka, te točke ili rečenice u istom stavku, odvojene od broja članka ili stavka točkom. Više će stavaka ili točaka istoga članka ili stavaka međusobno biti odvojeno zarezom. Crtica između brojeva dvaju članaka ili stavaka koristit će se radi označavanja da se sve odredbe između tih brojeva odnose na tekst ispred njih. Za označavanje 
na drugi naznačeni način dolazi do ordinacije te nadležnosti. ${ }^{2}$ Tzv. generička (prezidentalistička) $^{3}$ delegacija mjesne nadležnosti nema značenje delegacije mjesne nadležnosti u pojedinim parničnim postupcima (arg. ex 11. ZS). ${ }^{4}$

Zajedničkoje nužnoj i svrhovitoj delegaciji mjesne nadležnosti da se tiču slučajeva u kojima funkcionalno nadležni viši sud određuje niži (u pravilu prvostupanjski, ali, uz određene uvjete, i drugostupanjski) sud koji će biti mjesno nadležan odlučivati u određenom predmetu umjesto suda koji je po zakonu tako nadležan. Nadležnost delegiranog suda u konkretnom predmetu po oba navedena tipa delegacije neće se, dakle, temeljiti izravno na zakonu, već na odluci nadređenog suda (forum iudiciale). ${ }^{6}$ Oni se, međutim, ipak, razlikuju po pretpostavkama i postupku njihove primjene te učincima koji proizvode.

Funkcija je i nužne i svrhovite delegacije mjesne nadležnosti u pojedinim slučajevima pomoćna i/ili korektivna - njima se pribjegava kad za to postoji procesna nužda, dakle, kad po zakonu nadležan sud ne može postupati (nužna delegacija), odnosno kad se pokaže da bi bilo oportunije da u nekom predmetu sudi neki drugi sud a ne onaj koji je po zakonu mjesno nadležan (svrhovita delegacija). Premda se kod delegacije mjesna nadležnost neposredno utemeljuje odlukom višega suda, i u tim slučajevima sudi sud čija je nadležnost utvrđena u skladu sa zakonom, jer viši sudovi svoje ovlaštenje delegirati mjesnu nadležnost izvode iz zakona.

Praktična je važnost instituta nužne delegacije nadležnosti relativno mala, posebno nakon nedavnih sukcesivnih reorganizacija mreže općinskih sudova i njihova spajanja i time okrupnjavanja. S druge strane, institut svrhovite delegacije mnogo se češće primjenjuje u praksi, osobito u svojoj korektivnoj funkciji u kojoj u nekim slučajevima zapravo preuzima ulogu (moderirane) nužne delegacije.

Institutom ordinacije nastoje se premostiti blokade do kojih može doći u slučajevima u kojima (u pravilu) na temelju pravila o međunarodnoj nadležnosti postoji nadležnost hrvatskih sudova, ali se na osnovi važećih pravila o mjesnoj, uključujući i općemjesnoj, nadležnosti ne može utvrditi sud koji bi in concreto bio

pojedinih propisa koristit će se njihove kratice, koje će biti definirane u tekstu. Jedino će se odredbe Zakona o parničnom postupku (SL SFRJ 4/77 - 35/91; NN 26/91, 53/91, 91/92, 12/99, 88/01, 117/03, 88/05, 84/08, 123/08-ispr., 57/11, 25/13, 28/13 - ZS i 89/14.; ZPP; Zakon) navoditi bez naznake kratice.

2 Nazivi tih vrsta delegacija nemaju uporišta u zakonu - oni su doktrinarno-kvalifikacijske prirode.

3 Izraz je doktrinarna konstrukcija - usp. TRIVA-DIKA, Građansko parnično procesno pravo, 7. izd., 2004., 271. U nastavku ova će knjiga biti citirana kao TRIVA-DIKA, GPPP, uz naznaku broja stranice.

4 Prema Zakonu o sudovima (NN 28/13, 33/15, 82/15, 82/16; ZS.), predsjednik zajedničkog neposredno višeg suda ovlašten je (i dužan) odrediti da u pojedinoj vrsti predmeta postupa drugi stvarno i mjesno nadležni sud, ako sud koji je po zakonu stvarno i mjesno nadležan zbog velikog broja predmeta koje ima u radu ne može u razumnom roku raspraviti te predmete i donijeti odluku, zbog postizanja ravnomjerne opterećenosti sudova ili zbog promjena u stvarnoj i mjesnoj nadležnosti sudova (11/1. ZS).

5 Određivanje mjesne nadležnosti u slučajevima u kojima dolazi do sukoba o toj nadležnosti (22.24.) nije predmet ovog rada.

6 Usp. TRIVA-DIKA, GPPP, 271. 
mjesno nadležan. Praktična je važnost instituta ordinacije relativno mala. Taj će institut još više izgubiti na relevantnosti nakon stupanja na snagu novog Zakona o međunarodnom privatnom pravu (v. infra ad 4.).

Instituti nužne i svrhovite delegacije, kao uostalom i institut ordinacije nadležnosti, nepotpuno su uređeni, zbog čega bi, s teorijskog aspekta, njihova primjena u praksi mogla izazvati niz ozbiljnih problema. Ipak, zahvaljujući tome što se potreba za primjenom instituta nužne delegacije i ordinacije mjesne nadležnosti vrlo rijetko javlja u praksi, ti potencijalni problemi, kad je riječ o ta dva instituta, nisu imali odgovarajućeg odjeka u judikaturi. "Sudbina" sva ta tri instituta zapravo pokazuje kako se određenim intervencijama u organizaciju sudova i određivanje njihove nadležnosti može radikalno izmijeniti proceduralna važnost i značenje pojedinih instituta parničnog postupovnog prava.

Cilj je ovoga rada inicirati interes da se ozbiljnije počnu preispitivati neki od "tradicionalnih" instituta kompetencijskog građanskog postupovnog prava te skrenuti pozornost na njihovu važnost u urednom funkcioniranju pravozaštitnog sustava općenito. Cilj je ovog rada i upozoriti na mogućnost interferencije različitih procesnih instituta $u$ istom slučaju i potrebi njihove odgovarajuće interpretacije radi njihova primjerenja zahtjevima koji se nameću u pojedinim slučajevima.

\section{NUŽNA DELEGACIJA}

\subsection{Općenito}

Institut tzv. nužne delegacije uređen je odredbom članka 67. ZPP-a, po kojoj je nadležni sud, koji zbog izuzeća ili iz drugih razloga ne može postupati, dužan obavijestiti o tome neposredno viši sud, koji će odrediti da u tom predmetu postupa drugi stvarno nadležni sud s njegova područja. Nužna je delegacija, dakle, prenošenje mjesne nadležnosti odlukom teritorijalno neposredno višega suda (iste vrste) sa suda koji je po zakonu tako nadležan na drugi stvarno nadležni sud s područja tog višeg suda zato što sud koji je po zakonu mjesno nadležan ne može postupati u određenom predmetu. $^{7}$

Budući da glede toga u Zakonu nisu propisana nikakva ograničenja, nužna delegacija je moguća s jednog na drugi stvarno nadležan prvostupanjski sud odlukom neposredno višeg suda (iste vrste) na čijem se području ti sudovi nalaze, ali i s jednog na drugi drugostupanjski sud iste stvarne nadležnosti odlukom tim sudovima višeg suda na čijem se području oni nalaze (Vrhovnog suda).

O odnosu razloga za nužnu i svrhovitu delegaciju te o mogućoj interferenciji ovih dvaju instituta u praksi v. infra ad 2.11., ali i ad 3.4.5.

Smanjenju potrebe za primjenu instituta nužne delegacije, redovito zbog izuzeća sudaca, svakako pridonosi i "okrunjavanje" prvostupanjskih i, svakako, drugostupanjskih sudova, povećanje broja sudaca u tim sudovima.

7 Prije Novele 2003. nužnoj se delegaciji moglo pribjeći samo kada sud koji je po zakonu bio mjesno nadležan nije mogao postupati zbog izuzeća suca (sudaca) (prij. 67.). Novelom 2003. nužna je delegacija proširena na sve slučajeve u kojima sud koji je po zakonu mjesno nadležan ne može postupati u određenom predmetu (v. infra ad 2.4.). 


\subsection{Pretpostavke}

Iz supra ad 2.1. navedene odredbe članka 67. ZPP može se izvesti da je za određivanje nužne delegacije, u bitnome, potrebno da se kumulativno ispune ove pretpostavke:

(1) postupak u određenom predmetu treba biti pokrenut pred sudom koji je po zakonu mjesno nadležan (v. infra ad 2.3.),

(2) taj sud iz određenih razloga ne smije moći (trajno ili za određeno vrijeme) postupati u tom predmetu (v. infra ad 2.4.),

(3) on o toj nemogućnosti postupanja treba obavijestiti neposredno viši sud (iste vrste na čijem se području nalazi sud koji ne može postupati) (v. infra ad 2.5.) i

(4) sud na koji se nadležnost prenosi treba se (u načelu) nalaziti na području $a d$ (3) naznačenog neposredno višeg suda, treba biti stvarno nadležan i, svakako, treba moći postupati u predmetu koji će se na njega prenijeti (v. infra ad 2.6.).

Budući da glede toga nema nikakvih ograničenja, nužna bi delegacija bila moguća neovisno o tome po kojoj je osnovi zasnovana mjesna nadležnost suda koji ne može postupati, neovisno o tome je li on opće, elektivno, isključivo, atrakcijski ili prorogacijski mjesno nadležan.

\subsection{Postupak pokrenut pred mjesno nadležnim sudom}

Doslovno po Zakonu (67., v. supra ad 2.1.), nužna je delegacija moguća u slučajevima u kojima je postupak pred sudom koji je po zakonu mjesno nadležan već pokrenut u pojedinom predmetu, koji, međutim, iz bilo kojeg razloga, pravnog ili faktičnog, ne može u njemu postupati. Naime, prema toj odredbi, obavijest neposredno višem sudu o nemogućnosti postupanja treba uputiti sud koji je po zakonu mjesno nadležan, a koji će to moći učiniti tek nakon što mu tužba bude podnesena.

Prije Novele 2003. takva impostacija mogućnosti iniciranja postupka nužne delegacije nije izazivala nikakvih problema jer se o izuzeću suca (sudaca) moglo odlučiti tek nakon što bi postupak bio pokrenut (arg. ex 72.), zbog čega se tek tada moglo i postaviti pitanje takve delegacije. Nakon Novele 2003., proširenjem mogućnosti nužne delegacije na sve slučajeve u kojima sud $u$ konkretnom predmetu ne može postupati, postalo je aktualno pitanje može li se nužnoj delegaciji pribjeći i prije pokretanja postupka, i to na inicijativu potencijalnoga tužitelja. Naime, ako bi neki sud bio apsolutno spriječen postupati, trajno ili za određeno vrijeme, tužitelj se ne bi imao kome obratiti, pa se onda ne bi ni mogla ispuniti standardna pretpostavka za nužnu delegaciju - da se ona određuje u povodu obavijesti suda koji ne može postupati u konkretnom predmetu, dakle nakon što je postupak pred njime pokrenut. Upravo se stoga otvara dilema treba li u takvim slučajevima, mutatis mutandis (per analogiam, per necessitatem), primijeniti pravilo o nužnoj delegaciji ili o ordinaciji (69., v. infra ad 4.), odnosno na temelju tih instituta kreirati jedan novi koji bi bio primjeren specifičnostima postavljenog problema. U prilog nužne delegacije govorila bi okolnost da se u razmatranom slučaju znade koji je sud mjesno nadležan po zakonu, ali da, zato što ne može postupati u pojedinom sporu, treba odlučiti o prijenosu 
nadležnosti na drugi stvarno nadležan sud, a u prilog ordinacije realitet da se sud na koji bi mjesnu nadležnost trebalo delegirati treba odrediti da bi se znalo pred kojim se sudom postupak uopće može pokrenuti. Čini se da bi trebalo zauzeti stav da je zapravo riječ o jednom prijelaznom slučaju koji izlazi izvan matrica nužne delegacije i ordinacije mjesne nadležnosti stricto sensu, o slučaju za koji bi trebalo izgraditi modificirani institut nužne delegacije kojoj bi se pribjegavalo i u povodu inicijative potencijalnog tužitelja koji - iz raznih razloga - ne bi mogao pokrenuti postupak pred sudom koji je po zakonu mjesno nadležan.

Valja uzeti da bi u slučajevima u kojima prvostupanjski sud ne bi mogao postupati, ali u kojima iz analognih razloga ne bi mogao postupati ni neposredno viši sud pa ni delegirati predmet na drugi stvarno nadležni prvostupanjski sud sa svoga područja, nužnu delegaciju određivao Vrhovni sud kao funkcionalno "viši” sud prvostupanjskom sudu, iako formalno ne i neposredno viši, koji bi u biti to i postao jer neposredno viši sud ne bi moga obaviti svoju zadaću.

U praksi će se slučajevi u kojima određeni sudovi neće uopće moći postupati redovito prevladavati na širem planu, između ostaloga i tzv. generičkom delegacijom nadležnosti $^{8}$ (v. infra ad 2.12.) ili određivanjem novog sjedišta suda (v. infra ad 2.13.), ali i pribjegavanjem tzv. svrhovitoj delegaciji.

\subsection{Nemogućnost postupanja}

Nemogućnost postupanja suda koji je po zakonu nadležan može biti pravna, npr. zbog izuzeća jedinog suca ${ }^{9}$ ili svih od više sudaca, ili faktična, npr. zbog smrti jedinog ili više sudaca, njegove ili njihove duže bolesti, općenito zbog prestanka rada u sudu iz različitih razloga, itd.

Premda bi, doslovno po Zakonu, za nužnu delegaciju bilo dovoljno samo to da mjesno nadležni sud zbog izvjesnih razloga ne može postupati u određenom momentu, ipak bi nužnoj delegaciji trebalo pribjegavati samo kad se može pretpostaviti da bi nemogućnost postupanja trajala toliko dugo da bi to opravdavalo prenošenje nadležnosti. Tu bi standard razumnog roka u kojemu se postupak treba provesti (arg. ex 29/1. URH, 10/1. ZPP, 11/1., 63.-70. ZS) mogao poslužiti kao implicirani kriterij za određivanje vremenskog trajanja nemogućnosti postupanja.

\subsection{Obavijest o nemogućnosti postupanja}

Obavijest o nemogućnosti postupanja daje "sud" (u smislu organizacijske jedinice sudbene vlasti) pred kojom se vodi postupak u kojemu se ne može postupati, a ne sudac koji vodi taj postupak. Zato tu obavijest neposredno višem sudu upućuje predsjednik suda koji je po zakonu mjesno nadležan, u povodu inicijative suca koji smatra da se u određenom predmetu ne može postupati ili po službenoj dužnosti, npr. u povodu zahtjeva za izuzeće. Na to upućuje i odredba po kojoj je sudac koji

$8 \quad$ V. bilj. 4.

9 Nakon reorganizacije mreže sudova i njihovog značajnog okrupnjavanja slučajevi u kojima bi neki (općinski) sud mogao imati samo jednog suca su zapravo teško zamislivi. 
je saznao za postojanje kojeg od razloga za isključenje (71.1. - 6.) dužan prekinuti svaki rad na predmetu i o tome obavijestiti predsjednika suda, koji mu treba odrediti zamjenika. Ako je riječ o izuzeću predsjednika suda, on sam sebi određuje zamjenika iz reda sudaca tog suda, a ako to nije moguće, dužan je o tome obavijestiti neposredno viši sud radi nužne delegacije (72/1.) - $\mathrm{i}$ to, treba uzeti, ne u funkciji suca koji vodi postupak već predsjednika suda.

O slučajevima u kojima u sudu koji je po zakonu mjesno nadležan nema nikoga tko bi mogao uputiti obavijest neposredno višem sudu i o mogućnosti da stranka inicira delegaciju odnosno ordinaciju v. supra ad 2.3.

Obavijest o nemogućnosti postupanja ima zapravo oblik denuncijacije o određenom postupovnopravnom stanju i, eventualno, o potrebi delegacije, a ne akta kojim se, kao kod tzv. svrhovite delegacije, traži delegacija nadležnosti (v. 2.2., 2.3.). Ipak, neposredno je viši sud dužan postupiti u povodu takve obavijesti - određivanjem delegacije ili konstatacijom da za to nema uvjeta, u oba slučaja posebnim rješenjem.

$\mathrm{U}$ obavijesti o nemogućnosti postupanja ne treba biti naznačen drugi sud $\mathrm{s}$ područja neposredno višeg suda na koji bi nadležnost eventualno trebalo prenijeti. O tome slobodno odlučuje neposredno viši sud.

\subsection{Nužna delegacija suda višeg stupnja}

Članak 67. ZPP je tako stipuliran da se može primijeniti i u slučajevima u kojima određeni drugostupanjski sud ne može zbog izuzeća ili iz drugih razloga postupati u konkretnom predmetu u povodu pravnoga lijeka ili nekog drugog pravnog sredstva. Praktično u takvoj se situaciji mogu naći samo pojedini županijski sudovi. Dakle, Vrhovni bi sud u takvim situacijama trebao donijeti odluku o delegaciji funkcionalne (mjesne) nadležnosti sa županijskog suda koji je po zakonu funkcionalno (mjesno) nadležan na neki drugi županijski sud, vodeći računa o tome da se predmet smije prenijeti samo na županijski sud koji je stvarno nadležan za njegovo rješavanje (v. infra ad 2.11.).

\subsection{Neposredno viši sud}

Prema Zakonu nužnu delegaciju određuje neposredno viši sud, treba uzeti iste vrste. Kad je riječ o općinskim sudovima, neposredno viši sud je županijski sud na čijem se području nalazi općinski sud s koga nadležnost treba prenijeti i općinski sud na koji je treba prenijeti, kad je riječ o trgovačkim sudovima, neposredno viši sud je Visoki trgovački sud, a kad je riječ o županijskim sudovima, Vrhovni sud.

Ratio inzistiranja na tome da se nužna delegacija provodi s jednog na drugi sud na području zajedničkog neposredno višeg suda treba tražiti u impliciranom pravnopolitičkom stavu da sud na koji se nadležnost prenosi treba teritorijalno biti što bliži sudu s kojega se ona prenosi kako bi se takvim prenošenjem nadležnosti u što manjoj mjeri dovelo u pitanje pravo na suđenje pred sudom čija je nadležnost utvrđena zakonom, npr. prava tuženika da mu sudi sud na području kojega je njegov opći forum. Prihvaćeno je rješenje, zapravo, kompromis, s jedne strane, između navedenog prava 
na sud čija je nadležnost utvrđena zakonom, a, s druge strane, u situaciji kad taj sud ne može iz faktičkih ili pravnih razloga postupati, prava na pristup sudu, na suđenje općenito, odnosno na suđenje pred nepristranim i nezavisnim sudom.

Doslovno po Zakonu (67.), za utvrđivanje suda koji će biti funkcionalno nadležan za određivanje nužne delegacije mjerodavan je teritorijalni kriterij - to je zajednički neposredno viši sud za sud koji ne može postupati i za sud na koji se zbog toga mjesna nadležnost treba prenijeti.

Prema Zakonu o područjima i sjedištima sudova iz $2014 .{ }^{10}$ svi županijski sudovi nemaju jednaku drugostupanjsku nadležnost, jer su samo neki od njih ovlašteni odlučivati o žalbama podnesenim protiv prvostupanjskih odluka općinskih sudova donesenih u određenim posebnim vrstama sporova (4. ZPSS). Zato se može postaviti pitanje koji bi od županijskih sudova različite drugostupanjske nadležnosti trebao biti funkcionalno nadležan određivati nužnu delegaciju - županijski sud koji je po teritorijalnim kriteriju neposredno viši sudu s kojega mjesnu nadležnost treba prenijeti i sudu na koji je treba prenijeti, neovisno o tome je li "stvarno" nadležan odlučivati o žalbama protiv odluka tih sudova donesenim u vrsti sporova kojoj pripada spor u kojemu treba odrediti nužnu delegaciju, ili neki od županijskih sudova koji su "stvarno" nadležni odlučivati o žalbama u toj vrsti sporova. Naime, prema novom uređenju stvarne nadležnosti županijskih sudova i pojam neposredno viši sud dobiva drukčije značenje - za odlučivanje o žalbama u nekim vrstama sporova nije više uvijek nadležan županijski sud na čijem se području nalazi određeni općinski sud, već samo neki od županijskih sudova koji će in concreto biti individualizirani primjenom "algoritamskog" kriterija. ${ }^{11} \mathrm{U}$ prilog prvog rješenja govorilo bi, ipak, više razloga. Prvo, odredba članka 67. ZPP, u svom doslovnom značenju, upućuje na neposredno viši sud koji bi bio određen prema teritorijalnom kriteriju. Drugo, i sam ZPSS kad normira područja i sjedišta županijskih i općinskih sudova polazi primarno od teritorijalnog kriterija pa tako područja županijskih sudova određuje prema područjima određenih općinskih sudova (arg. ex 2. ZPSS 14). Treće, teritorijalnofunkcionalni kriterij je u bitnome relevantan i kad je riječ o poslovima sudske uprave koje je ovlašten obavljati viši sud u odnosu na niže sudove. Četvrto, treba uzeti, taj je kriterij mjerodavan i za odlučivanje o sukobu nadležnosti (arg. ex 23/1. ZPP), dakle, za rješavanje pitanja koja su funkcionalno bliska. Peto, to se rješenje čini bitno pragmatičnijim. Po njemu bi se predmet za koji je mjesno nadležan općinski sud čije je područje na području određenog županijskog suda prenijelo na drugi općinski sud čije je područje također na području tog županijskog suda, dakle, s jednog na drugi teritorijalno bliski sud. Ako bi se prihvatio kauzalno-funkcionalni kriterij, tada bi područje cijele države bilo područje za koje bi "mjesno" bio nadležan županijski sud koji bi, prema "algoritamskom" kriteriju, postao stvarno nadležan odlučivati o žalbama u određenim vrstama sporova. Slijedeći logiku njegovog tako određenog područja, on bi mogao delegirati nadležnost i na bitno udaljeni sud, što bi moglo

10 NN 128/14; ZPSS.

11 Žalbeni se predmeti županijskim sudovima dodjeljuju u rad elektroničkom nasumičnom dodjelom, primjenom odgovarajućeg algoritma, sukladno odredbama Sudskog poslovnika (arg. ex 4., 5. ZSPS). Iznimno, ako je u povodu žalbe odluka ukinuta, predmet se, u slučaju ponovne žalbe, dodjeljuje istom županijskom sudu (5/2. ZPSS). 
dovesti u pitanje ostvarivanje temeljnih postulata od kojih polaze pravila o mjesnoj nadležnosti. Pored toga, viši bi sud po kauzalno-funkcionalnom kriteriju mogao biti bitno udaljen od suda čiju nadležnost treba delegirati i zbog toga se teže upoznati s pravom situacijom koja postoji u tom sudu, ali i u sudu na koji bi nadležnost trebalo prenijeti.

Ako na području županijskog suda kao neposredno višeg suda ne bi bilo općinskog suda na koji bi se nadležnost mogla prenijeti, tada bi o tome taj županijski sud trebao obavijestiti Vrhovni sud, koji bi, ako bi ocijenio da su za to ispunjeni uvjeti, nadležnost delegirao na stvarno nadležni sud s područja nekog drugog županijskog suda. Na prihvaćanje mogućnosti da o nužnoj delegaciji u naznačenom slučaju odlučuje Vrhovni sud upućivala bi logika instituta. Naime, ako na području određenog županijskog suda kao neposredno višeg suda ne bi bilo suda na koji bi se nadležnost mogla prenijeti, tada bi o prijenosu trebao moći odlučiti sud koji je neposredno viši tom županijskom sudu, koji bi, zato što županijski sud ne bi mogao obaviti svoju zadaću, preuzeo njegovu funkciju. U ovom bi slučaju, zapravo, interferirali razlozi za nužnu i svrhovitu delegaciji zbog čega bi u slučaju o kojemu je riječ institut nužne delegacije trebalo dopunski razviti korištenjem kompetencijskih rješenja propisanih za svrhovitu delegaciju (v. infra ad 3.).

\subsection{Vrijeme do kojega se može predložiti nužna delegacija}

Nužnu delegaciju treba moći zatražiti i nakon zaključenja glavne rasprave pred prvostupanjskim sudom pa sve do donošenja odluke, ali i radi obavljanja poslova njezine dostave. Naime, ako se ona ne odredi, neće biti suca koji će donijeti odnosno odluku, odnosno suca koji će obaviti radnje nužne za njezinu dostavu. Nužnu delegaciju je moguće odrediti i radi poduzimanja radnji pred prvostupanjskim sudom u povodu žalbe ili nekog drugog pravnog lijeka ili sredstva, npr. radi toga da bi se donijela odluka o prekidu postupka, da bi se odlučilo o zahtjevu za povrat u prijašnje stanje, itd. Analogno bi vrijedilo i za postupak pred drugostupanjskim sudom.

\subsection{Tijelo koje je u višem sudu funkcionalno nadležno odlučivati o nuž- noj delegaciji}

Zakonom nije izrijekom riješeno koje tijelo u neposredno višem sudu odlučuje o nužnoj delegaciji. Čini se da bi rješenju toga pitanja bilo moguće dvojako pristupiti. Prema jednoj mogućnosti, o tome bi odlučivao sudac pojedinac toga suda. Na to bi upućivale, per analogiam, arg. a cohaerentia, odredbe o sastavu suda u slučaju sukoba o nadležnosti (23/3.) i o tzv. svrhovitoj delegaciji (68/3., v. infra ad 3.6.4.1.). Prema drugoj mogućnosti, o nužnoj bi delegaciji odlučivao predsjednik neposredno višeg suda zato što on odlučuje i o izuzeću predsjednika nižeg suda, u povodu čega će se najčešće to pitanje i postavljati. U prilog takvom rješenju govorila bi i okolnost da je kod nužne delegacije riječ općenito o nemogućnosti suda da postupa, zatim okolnost da obavijest o nemogućnosti postupanja daje predsjednik suda nižeg stupnja (v. supra ad 2.5.), ali i odredba prema kojoj prijedlog za tzv. generičku delegaciju nadležnosti 
daje predsjednik suda nižeg stupnja, o kojemu odlučuje predsjednik neposredno višeg suda (11. ZS). U svakom slučaju riječ je o zakonskoj praznini koju bi trebalo prevladati prigodom neke od narednih novela Zakona.

\subsection{Određivanje drugog stvarno nadležnog suda}

Kod nužne delegacije neposredno viši sud prenosi nadležnost sa suda koji je po zakonu nadležan na drugi stvarno nadležni suda sa svoga područja. U tom smislu sud na koji se nadležnost prenosi treba biti sud iste vrste, istoga ranga ali i iste stvarne nadležnosti. Zbog toga, kad je riječ o sudovima iste vrste, npr. trgovačkim i županijskim sudovima, ali djelomično različite stvarne nadležnosti (v. 4., 5., 7., 8. ZPSS), prigodom nužne delegacije nadležnosti treba voditi računa o tome da sud na koji se nadležnost prenosi bude i stvarno nadležan za suđenje u prenesenom sporu. ${ }^{12}$ Inače bi se nužnom delegacijom mogla izmijeniti (“zaobići”) zakonski različito impostirana stvarna nadležnost pojedinih sudova određene vrste i stupnja, odnosno ranga.

Ipak, u slučajevima u kojima je po zakonu samo jedan od svih trgovačkih odnosno županijskih sudova nadležan rješavati određene sporove, npr. odlučivati o tužbi za poništaj arbitražnog pravorijeka (43. ZA), načelo procesne nužde zahtijevalo bi da se nadležnost za postupanje u konkretnom predmetu može prenijeti i na sud koji po zakonu nije nadležan. Takvom bi delegacijom delegirani sud postao ne samo mjesno već i stvarno nadležan za rješavanje odnosnog spora. Stav da u takvim slučajevima nužna delegacija ne bi bila moguća, implicirao bi pristajanje na uskratu pristupa sudu, zbog čega bi bio u protivnosti s Ustavom.

Nužnu delegaciju nadležnosti s jednog na drugi općinski sud obavlja županijski sud kao neposredno viši sud, s jednog na drugi trgovački sud Visoki trgovački sud, a s jednog na drugi županijski sud Vrhovni sud. U slučajevima u kojima bi na području nekog županijskog suda postojao samo jedan općinski sud, za nužnu bi delegaciju bio nadležan Vrhovni sud jer bi on bio neposredno viši sud općinskom sudu čiju nadležnost treba prenijeti i općinskom sudu na koji je treba prenijeti.

Neposredno viši sud nije vezan za ocjenu nižeg suda o tome da ne može postupati u konkretnom predmetu. To znači da viši sud može odlučiti da je u konkretnom predmetu dužan postupati sud koji je po zakonu nadležan.

Glede dopuštenosti i osnovanosti inicijative za nužnu delegaciju vrijedilo bi na odgovarajući način ono što vrijedi i za svrhovitu delegaciju (v. infra ad 3.6.4.4.).

\subsection{Nužna i svrhovita delegacija}

Nužna se delegacija razlikuje od svrhovite (68., v. infra ad 3.) po tome što je pretpostavka za nužnu delegaciju nemogućnost postupanja suda koji je po zakonu mjesno nadležan, dok se svrhovitoj delegaciji pribjegava kad je očito da će drugi

12 Prema ZPSS iz 2010. (NN 144/10, 84/11) postojali su općinski sudovi različite stvarne nadležnosti (arg. ex 3. ZPSS 10), dok prema važećem uređenju svi oni imaju istu stvarnu nadležnost (arg. ex 2. ZPSS 14), što je bilo moguće postići njihovim “okrupnjavanjem”. 
sud lakše provesti postupak ili ako za to postoje drugi važni razlozi. Ratio prve jest procesna nužda, druge (u pravilu) procesni oportunitet. Ipak, u praksi razlozi za ove dvije delegacije mogu interferirati. Naime, nemogućnost postupanja ili otežana mogućnost postupanja mogu se smatrati i drugim važnim razlozima zbog kojih se može odrediti svrhovita delegacija.

Ipak, i u slučajevima u kojima zbog određenih razloga sud ne bi mogao postupati, dakle, u kojima bi bila ispunjena osnovna pretpostavka za nužnu delegaciju (67., v. supra ad 2.4.), moglo bi se pribjeći svrhovitoj delegaciji, npr. onda kada bi se pokazalo da bi bilo potrebno mjesnu nadležnost prenijeti na sud koji se ne bi nalazio na području neposredno višeg suda. Do toga bi, npr. moglo doći kada bi zbog izuzeća sudaca trebalo odrediti drugi sud izvan područja neposredno višeg suda. U takvoj bi situaciji Vrhovni sud trebao delegirati nadležnost. V. supra ad 2.8., ali i infra ad 3.5.4.

Trebalo bi zapravo zauzeti i stajalište da bi u slučajevima u kojima bi koincidirali (interferirali) razlozi za nužnu i svrhovitu delegaciju trebalo optirati za onu od njih koja bi omogućavala da se u što potpunijoj mjeri postigne ono što je pravozaštitni cilj svake od njih - što potpunije ostvarivanje prava na sud i prava na pravično suđenje $u$ razumnom roku pred neovisnim i nepristranim sucem.

Nužnu bi delegaciju, per necessitatem, trebalo odrediti i u slučajevima u kojima bi za izvjesne pravne stvari bio nadležan samo jedan prvostupanjski sud višeg ranga, kao što je to, npr., za donošenje odluke o zabrani štrajka ili isključena s rada kad štrajk ili isključenje s rada obuhvaća područje dviju ili više županija stvarno i mjesno nadležan samo Županijski sud u Zagrebu (219/2. ZR), ${ }^{13}$ a razlozi za izuzeće bi se ticali svih sudaca toga suda. U takvim bi slučajevima Vrhovni sud trebao kao (stvarno i) mjesno nadležan delegirati neki drugi županijski sud, koji, strogo po zakonu, ne bi bio stvarno nadležan (slučaj nužne delegacije stvarne nadležnosti).

Nakon što bi došlo do nužne delegacije, delegirani bi sud mogao predložiti svrhovitu delegaciju - ako bi za to bili ispunjeni propisani uvjeti, između ostaloga, predložiti da se nadležnost vrati na sud s kojega mu je prenijeta, npr. zato što su $\mathrm{u}$ međuvremenu prestali razlozi zbog kojih je nužna delegacija bila određena. ${ }^{14}$

\subsection{Nužna i generička delegacija}

Slučajevi u kojima određeni sud ne može postupati u pojedinom predmetu mogu se podudarati s (privremenom ili trajnom) nemogućnošću nekog suda da uopće postupa ili samo u nekoj kategoriji predmeta. U takvim bi slučajevima razlozi za pojedinačnu nužnu delegaciju u većem broju predmeta ili u svim predmetima mogli koincidirati s onima za tzv. generičku delegaciju $\left(11 / 1\right.$. ZS) ${ }_{1}^{15}$ pri čemu se ova druga čini primjerenijim načinom rješavanja takvih situacija.

13 ZR: Zakon o radu, NN 93/14.

14 U tom smislu i VSRH: Gr1-207/04 - IO 1/04-262.

15 V. 4. bilj. 


\subsection{Privremeno određenje drugog sjedišta suda}

Ako zbog više sile sud nije u mogućnosti djelovati u svojem sjedištu, ministar pravosuđa dužan je donijeti odluku kojom će privremeno odrediti drugo sjedište suda dok stanje više sile traje (10. ZPSS). Određivanjem drugog sjedišta određenog suda, npr. na području nekog drugog suda iste vrste, ne mijenja se mjesna nadležnost suda koji je dobio drugo sjedište - taj će sud poslove iz svoje stvarne i mjesne nadležnosti obavljati u svom novom sjedištu. Zato je moguća nužna delegacija mjesne nadležnosti i takvog suda - uz ispunjenje propisanih pretpostavaka.

\subsection{Detaširanje i premještanje sudaca}

De lege lata nema više zakonskog uporišta za detaširanje odnosno za premještaj sudaca jednog suda u drugi sud iste vrste u slučajevima u kojima suci tog suda ne mogu zbog izuzeća ili iz drugih razloga postupati. Bila je riječ o zakonskoj mogućnosti kojom su se, između ostaloga, mogle prevladati neke od situacija u kojima je potrebno odrediti nužnu delegaciju. ${ }^{16}$

\subsection{Problem nenadležnosti delegiranog suda i izazivanje sukoba o nad- ležnosti}

Treba uzeti da bi po općim pravilima prigovor apsolutne i stvarne bilo moguće istaknuti i u postupku pred delegiranim sudom, osobito u slučajevima u kojima prije donošenja odluke o delegaciji strankama ne bi bilo omogućeno da se o tome izjasne.

\section{SVRHOVITA (SVRSISHODNA) DELEGACIJA}

\subsection{Određenje pojma i pretpostavke}

Svrhovita delegacija jest prenošenje mjesne nadležnosti u "pojedinom predmetu" sa suda pred kojim je postupak u tijeku i koji je po zakonu tako nadležan na drugi stvarno nadležni sud u državi, na temelju odluke najvišeg suda određene vrste donesene u povodu inicijative suda koji je po zakonu mjesno nadležan, zato što je očito da će se tako lakše provesti postupak ili zato što za to postoje drugi važni razlozi (arg. ex 68.). ${ }^{17}$

Za svrhovitu delegaciju trebaju kumulativno biti ispunjene ove pretpostavke:

(1) treba biti pokrenut postupak pred sudom koji je po zakonu stvarno i mjesno nadležan (v. infra ad 3.2.); ${ }^{18}$

16 Prema ZS 2011, sudac je mogao uz svoj pristanak biti privremeno upućen na rad u drugi sud istog stupnja, na zahtjev predsjednika suda u koji se upućuje (102/3.). Rješenje o privremenom upućivanju na rad u drugi sud donosio je predsjednik zajedničkog neposredno višeg suda, uz obavijest Državnom sudbenom vijeću (102/4.).

17 Ovaj se izraz doktrinarna konstrukcija (usp., npr., TRIVA-DIKA, GPPP, 282., koji za ovaj oblik delegacije nadležnosti koriste izraz svrsishodna delegacija) koji je prihvaćen i u sudskoj praksi.

18 U tom je smislu suđeno da do svrsishodne delegacije ne može doći prije nego što tužba bude 
(2) treba postojati koji od razloga za svrhovitu delegaciju (v. infra ad 3.3.);

(3) sud koji je po zakonu nadležan mora zatražiti (prijedlogom) od najvišeg suda određene vrste da je odredi (v. infra ad 3.2.); ${ }^{19}$

(4) sud na koji se nadležnost predlaže prenijeti treba (u pravilu) biti označen u zahtjevu za delegaciju (arg. ex 68/1.) ${ }^{20}$

(5) sud na koji se nadležnost predlaže prenijeti treba biti stvarno nadležan.

Za svrhovitu delegaciju nije bitno kakva je mjesna nadležnost čije se prenošenje traži: delegirati se može, lege non distinguente, i isključiva mjesna nadležnost, ali i mjesna nadležnost utemeljena na sporazumu o mjesnoj nadležnosti.

Kad je riječ o delegaciji prorogirane mjesne nadležnosti suda koji je traži, treba poći od toga da je prorogacija osnova za to da određeni sud postane mjesno nadležan jednako kao i druge nadovezane okolnosti za utemeljenje te nadležnosti. Razlozi koji opravdavaju delegaciju su, međutim, razlozi zbog kojih bi već utemeljenu mjesnu nadležnost, neovisno o tome kako je do toga došlo, trebalo prenijeti na neki drugi sud. Ipak, prigodom odlučivanja o delegaciji prorogirane mjesne nadležnosti trebalo bi uzeti u obzir okolnost da je nadležnost suda koji traži delegaciju utemeljena na sporazumu stranaka, sporazumu koji ima značenje jače osnove za utemeljenje nadležnosti od drugih zakonskih osnova, osim onih koji dovode do isključive mjesne nadležnosti (arg. ex 70/1.).

\subsection{Sud koji predlaže delegacïju}

Doslovno prema Zakonu, svrhovitu delegaciju predlaže "nadležni sud prvog stupnja" (68/1.). On odlučuje i o prijedlogu stranke za svrhovitu delegaciju (68/2.). O njegovom pak prijedlogu odlučuje sudac pojedinac najvišeg suda određene vrste (68/3.). Pritom, pod pojmom prvostupanjskog suda u kontekstu odredaba članka 68. ZPP trebalo bi razumjeti sud u sastavu u kojemu vodi postupak.

Sud koji predlaže delegaciju treba biti u tom postupku stvarno i mjesno nadležan. Naime, ako nije nadležan, dužan je, u granicama u kojima je na to ovlašten, oglasiti se nenadležnim i ustupiti predmet nadležnom sudu (arg. ex 17., 20/2.). Ipak, budući da prvostupanjski sudovi u parničnom postupku u pravilu više ne paze po službenoj dužnosti na svoju mjesnu nadležnost (arg. ex 20.), sud pred kojim je postupak pokrenut mogao bi, redovito nakon što bi tuženik propustio istaknuti prigovor mjesne nadležnosti do upuštanja u raspravljanje o glavnoj stvari (20/1.), predložiti svrhovitu delegaciju ako bi ocijenio da za to postoje važni razlozi. Pritom bi on mogao predložiti da se nadležnost prenese na sud koji bi po zakonu bio mjesno nadležan, da bi u tome

podnesena (VSH: R-112/88 - PSP 40/90).

19 Upravo je zbog toga odbačen prijedlog za delegaciju koji je stranka izravno uputila Vrhovnom sudu - usp.: VSRH: Gr1-75/13-2 od 24. travnja 2013.

20 Odredba stavka 1. članka 68. glasi: "Nadležni sud prvog stupnja može sam ili na prijedlog stranke zatražiti od najvišeg suda određene vrste da odredi da u pojedinom predmetu postupa drugi stvarno nadležni sud s njegova područja ako je očito da će se tako lakše provesti postupak ili ako za to postoje drugi važni razlozi”. 
bili važni razlozi za delegaciju in concreto. ${ }^{21} 22$

Iako bi iz supra navedenih odredaba članka 68. ZPP proizlazilo da bi svrhovitu delegaciju mogao predložiti samo sud pred kojim je u tijeku prvostupanjski postupak, ${ }^{23}$ ipak bi trebalo dopustiti i svrhovitu delegaciju sa županijskog suda koji je po zakonu funkcionalno nadležan odlučivati kao sud drugog stupnja na drugi županijski sud u državi - ako bi županijski sud na koji bi nadležnost trebalo prenijeti lakše proveo postupak ili ako bi za to postojali drugi važni razlozi. To bi nalagala logika instituta svrhovite delegacije, npr. potreba da drugostupanjski sud na raspravi ponovno izvede sve dokaze koje je izveo prvostupanjski sud (373.b). U tom bi slučaju odredbe o svrhovitoj delegaciji koje su propisane za sudove prvog stupnja trebalo primijeniti na odgovarajući način. ${ }^{24} \mathrm{U}$ tom je smislu suđeno da da se može odrediti da u pojedinom predmetu postupka drugi žalbeni sud, ${ }^{25}$ odnosno da je to što je drugostupanjski sud koji bi trebao u ovršnom postupku odlučivati o žalbi protiv prvostupanjskog rješenja ovršenik u tom postupku važan razlog koji opravdava delegaciju drugog drugostupanjskog suda. ${ }^{26} \mathrm{I}$ iz judikata prema kojemu prijedlog za delegaciju drugog drugostupanjskog suda nije dopušten dok se još vodi postupak pred prvostupanjskim sudom, jer je takav prijedlog dopušten samo dok traje postupak pred sudom čija se delegacija traži, ${ }^{27}$ može se izvesti zaključak o tome da sudska praksa prihvaća

21 Npr. ako bi se time bitno olakšalo procesnu poziciju tuženika koji se nalazi u prekarnoj egzistencijalnoj situaciji i koji je iz neznanja propustio prigovoriti mjesnoj nenadležnosti suda kome je tužbe podnesena.

22 U naznačenom smislu institut svrhovite delegacije mogao bi biti iskorišten i za "zaobilaženje" ili otklanjanje negativnih posljedica (relativnog) isključenja mogućnosti da sud ex officio pazi i reagira na svoju mjesnu nenadležnost.

23 Prije Novele 2003. o svrhovitoj delegaciji odlučivalo se "na prijedlog stranke ili nadležnog suda" (prij. 68.). Upravo je stoga bilo moguće da svrhovitu delegaciju predloži i drugostupanjski sud kao "mjesno" nadležan sud.

24 Županijski bi sudovi svoju odluku da zatraže delegaciju donosili ex officio ili u povodu prijedloga stranke iznesenog u žalbi ili tijekom drugostupanjskoga postupka, npr. na sjednici vijeća ili na drugostupanjskoj raspravi. Odredbe članka 68. ZPP trebalo bi zapravo shvatiti kao odredbe koje, nepotpuno uređujući samo delegaciju mjesne nadležnosti tijekom postupka pred prvostupanjskim sudom, ne isključuju mogućnost da se ona zatraži i tijekom postupka pred drugostupanjskim sudom. Neovisno o tome, prenošenje nadležnosti s jednog na drugi županijski sud moglo bi se u slučaju osobite potrebe postići i elastičnom primjenom pravila o nužnoj delegaciji (v. supra ad 2.), pri čemu bi se važnim razlozima zbog kojih nadležni županijski sud ne bi trebao postupati u pojedinom predmetu smatrali razlozi zbog kojih on ne bi mogao postupati.

25 VSRH: R-63/87 - PSP 35/151.

26 VSRH: Grl-121/2007 - INF-N 5655/07. U konkretnom slučaju javni je bilježnik donio rješenje o ovrsi na temelju vjerodostojne isprave protiv županijskog suda. U povodu prigovora, prvostupanjski je sud ukinuo provedene radnje i obustavio postupak. Uslijedila je žalba u povodu koje je trebao odlučivati sud protiv kojega je rješenje o ovrsi bilo doneseno. U povodu oficijelne inicijative drugostupanjskog suda, Vrhovni je sud delegirao drugi županijski sud da odluči o žalbi. U konkretnom slučaju delegacija koja je određena okvalificirana je kao svrhovita, iako su bile ispunjene pretpostavke za nužnu jer se županijski sud kao stranka u postupku izuzeo ex officio.

27 VSRH: Grl: 745/2012-2 - INF-br. 6290-6291/2014. Treba uzeti da prijedlog za takvu "anticipiranu delegaciju" ne bi bio dopušten već i stoga što se o njegovoj umjesnosti odlučuje s 
mogućnost svrhovite delegacije "mjesne" nadležnosti ne samo prvostupanjskih već i drugostupanjskih sudova. Delegacija drugostupanjskog suda mogla bi se tražiti tek nakon što bi žalba bila podnesena. ${ }^{28}$

\subsection{Razlozi za svrhovitu delegaciju}

\subsubsection{Općenito}

Sedes materiae tzv. svrhovite delegacije je u odredbama članka 68. ZPP (v. supra ad 3.1.) u kojima su postavljene i osnove za utvrđivanje (nekih od) razloga za tu delegaciju. Prema tim odredbama, svrhovita delegacija se određuje (1) ako je očito da će se tako lakše provesti postupak ili (2) ako za to postoje koji drugi važni razlozi (arg. ex 68/1.). Prema načinu na koji su impostirani razlozi za svrhovitu delegaciju bilo bi, na prvi pogled, moguće zaključiti da je ovaj institut motiviran samo razlozima procesnopravnog oportuniteta. Međutim, iako se taj institut u bitnome temelji na tim razlozima, njegov ratio nije samo u "golom" procesnopravnom oportunitetu, već i u procesnopravnom oportunitetu koji je u funkciji afirmacije zahtjeva načelne prirode, zahtjeva ostvarenju kojih, s jedne strane, treba poslužiti mogućnost prenošenja nadležnosti s jednog na drugi sud, ali koji, s druge strane, nameću i ograničenja u korištenju te mogućnosti. U tom smislu delegacija nadležnosti može korisno poslužiti u ostvarivanju načela suđenja u razumnom roku, procesne ekonomije i efikasnosti općenito. S druge strane, njenim se korištenjem ne bi smjelo ozbiljno dovesti u pitanje (izigrati ili, blaže rečeno, zaobići) ostvarivanje načela o pravu na zakonskog suda, na pravično suđenje, dezavuirati pravno-politički razlozi na kojima su zasnovana zakonska pravila o mjesnoj nadležnosti, itd. (v. infra ad 3.4.3.).

\subsubsection{Očitost lakše provedbe postupka}

Pravni standard očitosti da će delegirani sud lakše provesti postupak trebalo bi shvatiti u smislu da se na temelju okolnosti koje se iznose u prilog delegacije, $u$ prvom redu na temelju navoda u prijedlogu za delegaciju (stranke i) suda koji je traži i priloga uz njega, eventualno tužbe i odgovora na tužbu te priloga uz te podneske, kao i možebitnih likvidnih dokaza kojima su pokrijepljeni, može zaključiti da je očito (prima facie), dakle bez potrebe upuštanja u daljnje istraživanje, da će predloženi sud jednostavnije, brže, jeftinije, pa i učinkovitije provesti postupak. Zato, ako bi se iz prijedloga i onoga čime je potkrijepljen moglo zaključiti da bi sud koji je mjesno nadležan trebao angažirati sud čija se delegacija predlaže da kao zamoljeni sud obavi pretežni dio dokaznog postupka, tada bi postojali ozbiljni indiciji da bi delegacija na taj drugi sud bila opravdana. ${ }^{29}$ Tako je ocijenjeno da će se postupak lakše provesti

obzirom na stanje stvari u vrijeme odlučivanja, dakle u stadiju postupka u kojemu se o nečemu može odlučivati, dakle, ne u vrijeme kad se i ne zna hoće li uopće doći do tog stadija.

28 Usp.: VSRH: Gr-272/00 - IO 1/01-163; VSRH: Gr-13501 - IO 1/02-184.

29 Npr. s jednog na drugi općinski sud. Kad je riječ o trgovačkim sudovima, s obzirom na to da oni u načelu nisu stvarno nadležni za pružanje pravne pomoći, jedan od tih sudova ne bi mogao od drugog takvog suda tražiti da kao zamoljeni sud obavi određene radnje u pojedinom postupku. De lege ferenda, trebalo bi, eventualno, predvidjeti da trgovački sudovi jedni drugim 
pred sudom na čijem se području nalazi nekretnina s obzirom na koju treba provesti vještačenje te ostali dokazi koji se po prirodi stvari nalaze na njegovu području, ali i prebivalište odnosno sjedište tužitelja i gotovo svih tuženika. ${ }^{30} \mathrm{~S}$ druge strane smatralo se da nema značenje važnog razloga koji bi opravdavao svrhovitu delegaciju okolnost da više svjedoka koje treba saslušati nema prebivalište na području nadležnog suda, ${ }^{31}$ odnosno okolnost da će se dokaz očevidom uz sudjelovanje vještaka provesti u mjestu nastanka štetnog događaja, a koje je izvan mjesta nadležnog suda, ${ }^{32}$ kao ni okolnost da na području parničnog suda nema prikladnog vještaka. ${ }^{33}$

\subsection{3. "Drugi važni razlozi”"}

Utvrđenje postojanja “drugih važnih razloga” u pojedinim slučajevima, razloga koji su indicirani tek kvalifikativom "važni”, prepušteno je delegacijskim sudovima - oni su ovlašteni ocijeniti jesu li se neki od njih ili više njih realizirali in concreto.

Prigodom utvrđivanja postoje li drugi važni razlozi za svrhovitu delegaciju sud bi se također trebao zadržati na razini (u pravilu pretežnije) vjerojatnosti. Utvrđivanje pretpostavaka za takvu delegaciju ne bi smjelo postati samo sebi svrhom, pretvoriti se u "postupak u postupku".

Postojanje razloga za svrhovitu delegaciju treba usko tumačiti, između ostaloga i zato što se takvom delegacijom in concreto dezavuiraju zakonska pravila o mjesnoj nadležnosti i pravopolitička logika na kojoj se temelje. I kod te bi delegacije zapravo na specifičan način dolazilo do izražaja načelo proporcionalnosti: odstupanje od prava na zakonom ustanovljenog suda (16., 29/1. URH), što bi, između ostaloga, trebalo shvatiti i kao odstupanje od prava da sudi sud čija je nadležnost utvrđena zakonom, treba naći svoje opravdanje u ostvarivanju drugih temeljnih postupovnih prava, prava na pravično suđenje, prava na suđenje u razumnom roku, prava koja, uz ostalo, trebaju osigurati pružanje i kvalitetnije (istinitije - eventualno kroz ostvarivanje načela neposrednosti i slobodne ocjene dokaza), efikasnije (koncentracija u postupanju), jeftinije (i time dostupnije) itd. pravne zaštite.

Zamisliv je i slučaj da stranka predloži delegaciju i sud je odluči zatražiti zato što pred nekim drugim sudom teče ili teku postupci s kojima bi se postupak koji bi trebalo prenijeti mogao spojiti (prenošenje nadležnosti radi spajanja postupaka).

\subsubsection{Judikatura o drugim važnim razlozima}

U praksi je ocijenjeno da (drugi) važni razlozi za svrhovitu delegaciju postoje u slučaju u kojemu: - je tužitelj u parnici zatražio naknadu štete koja je navodno nastala uslijed propusta nadležnog suda; ${ }^{34}$ - je tužitelj sudac parničnog suda, ${ }^{35}$ odnosno jedna

kao zamoljeni sudovi pružaju pravnu pomoć - tome bi u prilog govorila i sve veća proceduralna diferencijacija postupka pred trgovačkim sudovima od one pred redovnim sudovima.

30 VSRH: Gr-1-573/02 - INF-N 5204-5205/04.

31 VSH: R-329/78 - NZp 11/79-76., VSRH: Gr-133/\&01 - INF br. 5032-5033/2002.

32 VSRH: Gr-133/01 - INF br. 5032-5033/2002.

33 VPSH: Rp-87/80 - PPP 7/84-63.

34 VSH: Gr-218/89 - PSP 46/90.

35 VSH: R-117/81 - NZp 19/82-134. 
od stranaka sudac suda kome je podnesena tužba; ${ }^{36}$ - se traži naknada štete uzrokovane radom parničnog suda; ${ }^{37}$ - je stranka bivši sudac parničnog suda; $;^{38}$ - je tužiteljeva kćerka sudac parničnog suda; ${ }^{39}$ - je predsjednik prvostupanjskog suda stranka u postupku; $; 0$ - je stranka radnik u manjem parničnom sudu; $;{ }^{41}$ - je predsjednik suda tuženikov zet; ${ }^{42}$ - je stranka predsjednik višeg suda nadređenog parničnom sudu: ${ }^{43}$ je tužitelj sudac nadređenog suda, a njegova je supruga sudac parničnog suda; ${ }^{44}$ - je protiv stranke podnesena kaznena prijava zbog vrijeđanja suda i raspravnog suda:45 - je tužitelj zatražio naknadu štete za koju tvrdi da je nastala zbog propusta suda kome je tužba podnesena:46 - je nezakonitu radnju od koje se traži zaštita učinio nadležni sud: ${ }^{47}$ - je tužiteljica predsjednica stvarno i mjesno nadležnog suda; ${ }^{48}$ - je sin tužiteljice sudac nadležnog suda; ${ }^{49}$ - je riječ o sporu koji je zbog svoje prirode od interesa i za ostale žitelje kraja i kojem djeluje tuženik, pa uz ostalo i od interesa za suce nadležnoga suda; ${ }^{50}$ - je tužitelj pokrenuo odštetnu parnicu protiv Republike Hrvatske tvrdeći da mu je šteta nanesena nezakonitim radom djelatnika nadležnoga suda; ${ }^{51}$ - je jedna od stranaka majka suca nadležnog suda: ${ }^{52}$ - je stranka brat predsjednika suda ${ }^{53}$ - je drugostupanjski sud stranka u postupku, a taj sud treba odlučivati o žalbi protiv odluke prvostupanjskog suda kojom se taj sud, u povodu tužbe za poništaj rješenja drugostupanjskog suda i za primitak tužitelja na radno mjesto višeg sudskog savjetnika, oglasio stvarno nenadležnim smatrajući da je stvarno nadležan Upravni sud u povodu; ${ }^{54}$ - je veliki broj državnih službenika odnosno namještenika određenog suda podnio tužbe tom sudu protiv Republike Hrvatske radi ostvarivanja tražbina iz iste pravne osnove; 55 itd.

S druge strane, zauzet je stav da ne postoji važan razlog za svrhovitu delegaciju u slučaju u kojemu: - je stranka bivši sudac nadležnog drugostupanjskog suda; ${ }^{56}$ je kao svjedok saslušan predsjednik parničnog suda; ${ }^{57}$ - je stranka općina na čijem

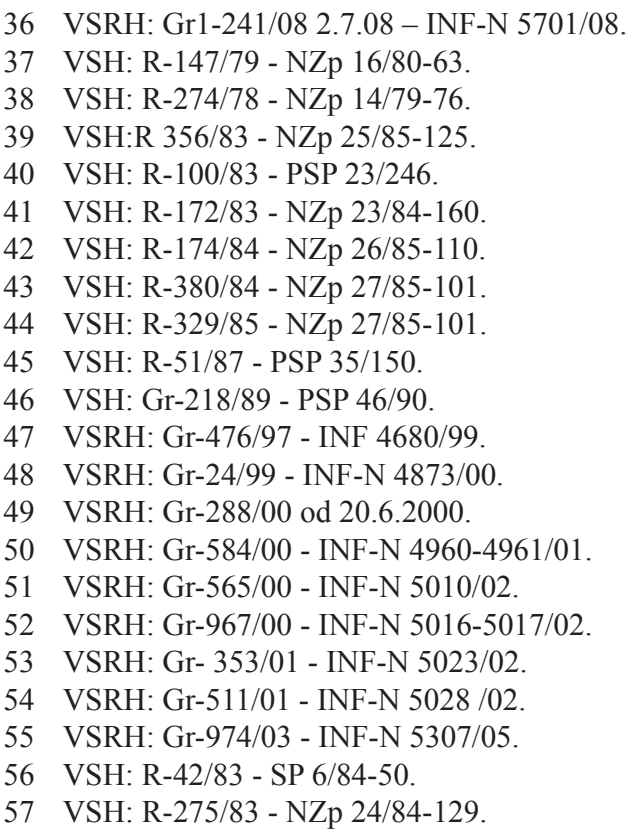


je teritoriju parnični sud; ${ }^{58}$ - je stranka zaposlena u parničnom sudu; ${ }^{59}$ - je stranka odvjetnik s uredom u središtu nadležnog suda; ${ }^{60}$ - je raspravni sudac pri poduzimanju procesnih radnja propustio voditi računa o potrebi da se postupak ne odugovlači; ${ }^{61}$ je tužitelju zbog loših materijalnih prilika teško putovati u sjedište nadležnog suda; ${ }^{62}$ - je supruga jedne od stranaka sudac nadležnog suda; ${ }^{63}$ - sud sporo rješava predmet ne pridržavajući se odredaba postupka, ${ }^{64}$ - tuženica i njen punomoćnik na ročištima vrijeđaju tužitelja; ${ }^{65}$ - stranka sumnja u objektivnost sudaca zato što je jedan od sudaca zet punomoćnika tuženika; ${ }^{66}$ - je supruga jedne od stranaka zaposlena kao upravitelj sudske pisarnice, ${ }^{67}$ - stranka sumnja u objektivnost vještaka pri davanju njegova nalaza i mišljenja; ${ }^{68}$ - je stranka prije obnašala dužnost županijskog državnog odvjetnika za područje nadležnog suda; ${ }^{69}$ - su kao stranke u postupku sudjelovali službenici općinskog i županijskog državnog odvjetništva s područja nadležnog suda; ${ }^{70}$ je tužiteljica zaposlenica i ranije ravnateljica lokalnog Centra za socijalnu skrb koja učestalo kao stručna osoba sudjeluje u postupcima iz obiteljskih odnosa kod prvostupanjskog suda, a koja je tužila radi naknade štete iz radnog odnosa taj Centar koji pruža sudu stručnu pomoć i sudjeluje gotovo svakodnevno u velikom broju postupaka te zaposlenika te iste pravne osobe, ${ }^{71}$

Izloženi stavovi zauzeti u judikaturi ne bi se smjeli smatrati pravilima kojih bi se najviši sudovi određene vrste trebali čvrsto držati - oni imaju značenje mogućih orijentira, indicija za ocjenu o postojanju razloga za svrhovitu delegaciju. Naime, odluka o prihvaćanju ili odbijanju inicijative za svrhovitu delegaciji u svakom se pojedinom slučaju treba temeljiti na specifičnim okolnostima toga slučaja, zbog čega su eventualne apodiktične generalizacije na temelju stavova zauzetih u judikaturi teško moguće.

\subsubsection{Razgraničenje razloga za svrhovitu i nužnu delegaciju}

Time što i drugi važni razlozi mogu biti osnovom za svrhovitu delegaciju, ovaj se institut približio razlozima zbog kojih se (osobito nakon Novele 2003.) može pribjeći nužnoj delegaciji. Zato bi trebalo nastojati utvrditi kriterije za razgraničenje njihove primjene. Tu bi bila moguća barem dva interpretativna pristupa.

Prema jednom interpretativnom pristupu, crta razgraničenja trebala bi biti u

58 VSH: R-155/83 - NZp 23/84-161.

59 VSH: R-288/84 - SP 12/85-53.

60 VSRH: Gr-216/93 - IO 1994/282.

61 VSRH: Gr-143/93 - IO 1994/281.

62 VSRH: Gr-408/93 - IO 2/1995-120.

63 VSRH: Gr-184/98 - INF-N 4868-4869/00.

64 VSRH: Gr-261/98 - INF-N 4825/00.

65 VSRH: Gr-103/99 - INF-N 4876-4877/00.

66 VSRH: Gr-256/00 od 27. 6. 2000.

67 VSRH: Gr-282/00 - INF 4925/01.

68 VSRH: Gr-2/00 - INF-N 4962-4963/01.

69 VSRH: Gr1-576/02 - INF-N 5190/03.

70 VSRH: Gr1-613/02 - INF-N 5182.

71 VSRH: Gr1-94/15-2 od 3. ožujka 2015. 
tome da razlozi koji bi dovodili do nemogućnosti postupanja suda koji je mjesno po zakonu nadležan, makar bi sami po sebi bili važni razlozi zbog kojih bi se moglo pribjeći i svrhovitoj delegaciji, ne bi mogli biti osnovom za takvu delegaciju - oni bi bili razlozi za nužnu delegaciju. Ovaj bi interpretativni pristup mogao biti omekšan stavom da bi se ipak i u slučajevima u kojima zbog određenih razloga sud ne bi mogao postupati, dakle u kojima bi bila ispunjena osnovna pretpostavka za nužnu delegaciju (67., v. supra ad 2.4.), moglo pribjeći svrhovitoj delegaciji. Tako bi, npr., u slučaju u kojemu bi se pokazalo da bi bilo opravdano mjesnu nadležnost prenijeti na sud koji se ne bi nalazio na području neposredno višeg suda, konkretno na području županijskog suda na čijem se području nalazi općinski sud koji ne može postupati u pojedinom predmetu, već na općinski sud koji se nalazi na području nekog drugog županijskog suda - trebalo pribjeći svrhovitoj delegaciji.

Prema jednoj drugoj interpretativnoj mogućnosti, u slučajevima u kojima bi koincidirali (interferirali) razlozi za nužnu i svrhovitu delegaciju trebalo bi optirati za onu od njih koja bi omogućavala da se u što potpunijom mjeri postigne ono što je pravozaštitni cilj svake od njih, odnosno općenito pružanje što kvalitetnije pravne zaštite, pravne zaštite koja bi jamčila što potpunije i uravnoteženije ostvarivanje temeljnih postupovnih postulata.

Kao drugi važni razlozi često se, kako to praksa pokazuje, javljaju razlozi koji, strogo uzevši, nisu motivirani procesnim oportunitetom, već i principijelnim razlozima, u prvom redu potrebom da se osigura veća razina objektivnosti u suđenju. Zato se i naziv svrhovita (svrsishodna) ${ }^{72}$ delegacija koji indicira procesni oportunitet kao određujući razlog za takvu delegaciju, pokazuje nedovoljno preciznim. ${ }^{73}$

\subsubsection{Stvarna nadležnost i sposobnost suda na koji bi delegaciju trebalo prenijeti da ispuni njezinu svrhu}

Sud na koji bi trebalo prenijeti nadležnost za rješavanje određenog spora treba biti stvarno nadležan za njegovo rješavanje. To znači da bi trgovački sud na koji bi trebalo prenijetu tu nadležnost trebao biti stvarno nadležan za rješavanje odnosnog spora. Tako, npr., mjesna se nadležnost sa Trgovačkog suda u Zagrebu za rješavanje nekog spora koji se odnosi na brodove i plovidbu na moru ne bi mogla prenijeti na Trgovački sud u Zadru jer ovaj sud nije stvarno nadležan za rješavanje te vrste sporova (arg. ex 7., 8. ZPSS). Slično bi vrijedilo i kad treba delegirati žalbene predmete s jednog na drugi županijski sud (arg. ex 4., 5. ZPSS).

Prigodom ocjene postoje li razlozi za delegaciju trebalo bi uzeti u obzir i kapacitet suda kojemu bi predmet trebalo delegirati, je li i kako je opterećen te bi li se prenošenjem nadležnosti na njega ostvarila svrha delegacije (v. i infra ad 3.5.).

72 V. bilj. 16.

73 Možda bi zato korektniji bio naziv delegacija mjesne nadležnosti iz važnih razloga. Ipak, s obzirom na ukorijenjenost naziva svrhovita delegacija i njegovu relativnu lapidarnost, taj bi izraz trebalo zadržati. 


\subsubsection{Supsidijarnost svrhovite delegacije}

Delegacija u načelu ne bi bila potrebna u slučajevima u kojima bi se neke radnje zbog provedbe kojih se traži prenošenje cijelog predmeta mogle relativno jednostavno obaviti preko zamoljenog suda, odnosno koje bi svrhovitije mogao obaviti sudac pojedinac odnosno predsjednik vijeća (pa i vijeće) suda koji vodi postupak na području drugog suda (25.).

\subsection{Svrhovita delegacija i suđenje u razumnom roku}

Jedan od (impliciranih) ciljeva svrhovite delegacije bi, svakako, trebalo biti i osiguranje suđenja u razumnom roku. U tom bi se smislu ona, uz ispunjenje općih uvjeta za njezino određivanje, mogla koristiti i kad bi u pojedinim predmetima bilo potrebno osigurati takvo suđenje. Postizavanje suđenja u razumnom roku trebalo bi, međutim, biti i jedan od momenata o kojemu bi (uvijek) trebalo voditi računa prigodom vaganja razloga za donošenje odluke o prenošenju nadležnosti - moment koji bi u nekim slučajevima sam po sebi mogao biti od odlučujuće važnosti.

\subsection{Postupak}

\subsubsection{Općenito}

Postupak u kojemu treba odlučiti o svrhovitoj delegaciji provodi se u četiri osnovna stadija: stadij donošenja odluke o predlaganju i podnošenja prijedloga, stadij odlučivanja o prijedlogu, stadij realizacije odluke o delegaciji i stadij postupka pred delegiranim sudom. Posljednja dva stadija ne provode se ako se prijedlog za delegaciju odbaci ili odbije.

Za vrijeme trajanja incidentalnog delegacijskog postupka, dakle, od podnošenja prijedloga za postavljanje zahtjeva za delegaciju ili od iniciranja ex officio toga postupka, do dostave odluke delegacijskog suda sudu koji ga je podnio kojim se prijedlog odbacuje ili odbija, odnosno do ustupanja predmeta delegiranom sudu, glavni se postupak ne prekida niti dolazi do njegova zastoja ( $\arg$. ex 212., 213., 215.a) - on teče kao i u drugim slučajevima u kojima se otvaraju pitanja nenadležnosti ili sukoba o nadležnosti (15.-24., v. $\S)$.

\subsubsection{Donošenje odluke da se delegacija zatraži}

Svrhovitu delegaciju sud može predložiti ex officio ili na prijedlog stranke (68/1.). ${ }^{74} 75$ Prijedlog može podnijeti jedna od stranaka, a mogle bi ga obje podnijeti zajednički ili konkurentno, s istim ili različitim argumentima. Pritom bi one mogle predložiti isti ili različiti sud kao sud na koji bi nadležnost trebalo prenijeti.

74 Prijedlog za delegaciju mogla bi kao tuženik, svakako, podnijeti i Republika Hrvatska, osobito stoga što može biti tužena u mjestu koje odgovara tužitelju (arg. ex 48, 49.).

75 Novelom 2003. je ograničeno pravo stranaka da traže izravno svrhovitu delegaciju jer se ono često zlorabilo u praksi. Prvostupanjski sud bi svakako trebao voditi računa i o tom momentu prigodom donošenja odluke o tome hoće li u povodu prijedloga stranke zatražiti delegaciju. 
O prijedlogu stranke odnosno prijedlozima stranaka sud odlučuje rješenjem protiv kojega žalba nije dopuštena (68/2.), što znači da taj pravni lijek nije dopušten neovisno o tome je li rješenjem prijedlog prihvaćen ili odbijen.

Sud koji bi našao da bi ex officio valjalo predložiti delegaciju, trebao bi strankama, u pravilu, omogućiti da se o tome prethodno izjasne (arg. ex 5., 7/3.). Pružanje strankama mogućnosti da se izjasne o možebitnoj svrhovitoj delegaciji bilo bi osobito važno zato što se prenošenjem mjesne nadležnosti sa suda koji je po zakonu (ili na temelju sporazuma stranaka) mjesno nadležan na drugi sud može ugroziti ostvarivanje njenog prava da joj sudi sud čija je nadležnost utvrđena zakonom (v. supra ad 3.4.), odnosno njeno pravo na pravično suđenje. Naime, stranci bi moglo biti bitno otežanije ostvarivanje prava na sudjelovanje u postupku pred delegiranim sudom, npr. zbog veće udaljenosti, povećanih troškova, nego što bi joj to bilo pred sudom koji je po zakonu nadležan.

Sud bi odluku o tome da se delegacija predloži trebao donijeti ne samo kad bi o tome odlučivao u povodu inicijative stranke, već i kad bi ocijenio da to treba učiniti ex officio. Ta bi odluka imala značenje rješenja o upravljanju postupkom $(278 / 2$, 288/4., 311/5.), na što upućuje i okolnost da protiv njega žalba nije dopuštena (arg. ex 68/2., 311/4., 343/2.). Tu bi odluku trebalo strankama dostaviti zajedno s možebitnim prijedlogom za delegaciju: po pravilima o dostavi rješenja protiv kojih žalba nije dopuštena (343/2.).

\subsubsection{Prijedlog za svrhovitu delegaciju}

\subsubsection{Stadiji postupka u kojima se delegacija može predložiti}

Prijedlog za svrhovitu delegaciju može se podnijeti tek nakon što je postupak pred prvostupanjskim sudom pokrenut. Prije toga nema "pojedinog predmeta" pred sudom koji je po zakonu mjesno nadležan, niti stranaka koje bi sudjelovale u postupku. Pored toga, prije nego što se tuženici u pokrenutom postupku o tome ne izjasne, nije moguće znati hoće li delegacija biti svrhovita. U tom smislu se izjasnila i judikatura. ${ }^{76}$ Delegacija se ne može predložiti ni nakon što dođe do povlačenja tužbe jer ni tada nema "pojedinog predmeta" u kojemu bi je trebalo zatražiti. ${ }^{77}$ Iako je suđeno da se delegacija ne može tražiti nakon što je postupak pravomoćno završen, ${ }^{78}$ treba uzeti da bi se ona mogla predložiti i u postupku u povodu prijedloga za ponavljanje postupka.

Stadij postupka u kojemu se koja od mogućih inicijativa za delegaciju poduzima i time uvjetovana razina "zrelosti" stvari za odluku u postupku pred nadležnim sudom, mogao bi biti relevantan za ocjenu njihove opravdanosti. Tako bi nakon zaključenja glavne rasprave bilo vrlo teško pronaći opravdane razloge za podnošenje prijedloga jer bi tada stvar u pravilu već bila zrela za donošenje odluke. Delegacija bi se mogla eventualno predložiti ako bi prvostupanjski sud preotvorio glavnu raspravu.

Županijski bi sud kao drugostupanjski delegaciju mogao predložiti tek nakon što bi mu predmet u povodu žalbe bio dostavljen te sve dok se o žalbi ne odluči.

76 VSH: R-174/72 - NZp 2/73-29; VSRH: Gr-266/00 - INF N 4939/01; VSRH: Gr-1034/01 - INF-N 5179/03.

77 VSRH: Gr-133/04 - INF-N-5287/04.

78 VSRH: Gr-497/97 -INF.N 4899/01. 


\subsubsection{Funkcionalna nadležnost za podnošenje prijedloga}

Prijedlog za delegaciju u prvostupanjskom postupku podnosi sudac pojedinac koji postupak vodi ili predsjednik vijeća u stvarima u kojima sudi vijeće, na temelju odluke vijeća, a ne predsjednik suda kao kod nužne delegacije (v. supra ad 2.5.). Naime, riječ je o radnji u okviru konkretnoga postupka koji se može provesti, a ne o radnji u postupku koji se ne može provesti i kojom se traži povjeravanje predmeta sudu koji bi to mogao učiniti kao kod nužne delegacije. Slično bi i u žalbenom postupku prijedlog podnosili sudac pojedinac koji vodi taj postupak ili predsjednik vijeća ako se postupak provodi pred vijećem

\subsubsection{Prijedlog za delegaciju}

Prijedlog za svrhovitu delegaciju treba biti supstanciran. On treba sadržavati i "delegacijski zahtjev", zahtjev da se donese odluka o delegaciji određenog sadržaja - uz odgovarajuće obrazloženje. Prijedlogu treba priložiti i spis jer on redovito sadrži podatke na temelju kojih se može formirati ocjena o stanju stvari, uključujući i zapisnike o izvedenim dokazima, odnosno same dokaze, npr. isprave.

U prijedlogu za delegaciju trebalo bi, u pravilu, naznačiti i sud na koji bi nadležnost trebalo prenijeti, jer ocjena o tome je li svrhovito delegirati nadležnost na neki drugi sud može se u pravilu donijeti samo uspoređivanjem uvjeta u kojima bi dva suda - onaj koji je po zakonu nadležan i onaj koji bi trebao postati nadležan - provela postupak. U prijedlogu bi se, eventualno, moglo naznačiti (indicirati) i dva ili više sudova na koje bi nadležnost trebalo prenijeti zato što bi svaki od njih postupak lakše proveo. Štoviše, iznimno, ako bi se delegacija tražila iz tzv. drugih važnih razloga, zapravo redovito iz razloga bliskih razlozima za tzv. relativno izuzeće (71.7.). ${ }^{79}$ bilo bi dovoljno zatražiti delegaciju na bilo koji drugi nespecificirani stvarno nadležni sud i prepustiti najvišem sudu određene vrste da odluči o tome koji bi to sud bio.

Prijedlog za delegaciju, međutim, nema značenje formalnog akta kojim bi viši sud bio vezan u sadržajnom smislu. On bi zapravo imao značenje akta u povodu kojega bi viši sud bio dužan postupiti i odlučiti, ali sadržajem čijeg zahtjeva ne bi bio vezan u smislu da bi ga morao ili prihvatiti ili odbiti; viši bi sud, već prema slučaju, bio ovlašten odlučiti i extra petita, npr. predmet delegirati nekom drugom sudu umjesto predloženom.

Sud koji bi zatražio delegaciju ne bi bio vezan za svoju odluku o tome i svoj bi prijedlog mogao povući sve dok se o njemu ne bi odlučilo. Naime, ta je odluka o materijalnom upravljanju postupkom i zato sud njome nije vezan (arg. ex 311/4., 343/3.).

O supstanciranosti i time uvjetovanoj uvjerljivosti samog prijedloga bi, svakako, ovisilo i njegovo prihvaćanje.

79 Prema odredbi članka 71. točke 7. ZPP sudac ne može obavljati sudačku dužnost ako postoje (druge) okolnosti koje dovode u pitanje njegovu nepristranost. 


\subsubsection{Podnošenje prijedloga i odlučivanje o prijedlogu}

\subsubsection{Sud funkcionalno nadležan odlučivati o delegaciji}

Prijedlog za delegaciju podnosi se najvišem sudu određene vrste (68/1.).

O prijedlogu za delegaciju odlučuje sudac pojedinac najvišeg suda određene vrste (68/1., 3.), dakle, ako delegaciju predloži općinski sud ili županijski sud, sudac pojedinac Vrhovnog suda ${ }^{80}$ a ako delegaciju predložio trgovački sud, Visoki trgovački sud kao najviši specijalizirani sud određene vrste. ${ }^{81}$

\subsubsection{Pribavljanje dopunskih izvješća i provedba izviđaja}

Iako to nije izrijekom predviđeno, sud koji odlučuje o delegaciji ovlašten je zatražiti od suda koji je predložio delegaciju, ali i od suda na koji bi nadležnost trebalo prenijeti odgovarajuća izvješća, odnosno provedbu određenih izviđaja (arg. per analogiam ex 360., 361., 399/1.); on bi potrebne informacije mogao zatražiti i od neposredno višeg suda. Delegacijski sud bi mogao, ako ocijeni da je to potrebno, zatražiti od suda koji je predložio delegaciju ili, ako je delegaciju predložio viši sud, od prvostupanjskog suda da sasluša i stranke. Po potrebi, trebalo bi zatražiti i očitovanje suda na koji bi nadležnost trebalo prenijeti.

\subsubsection{Moment relevantan za odlučivanje o osnovanosti prijedloga}

Za odlučivanje o prijedlogu relevantno je stanje stvari u vrijeme odlučivanja o prijedlogu, zapravo stanje stvari u vrijeme kad je delegacijski sud dovršio prikupljanje materijala na temelju kojega će odlučiti.

\subsubsection{Odlučivanje}

Sudac pojedinac najvišeg suda određene vrste odluku o prijedlogu za delegaciju donosi u obliku rješenja jer je riječ o odluci procesnog karaktera (arg. ex 129., 325.).

Prijedlog treba odbaciti ako se ocijeni da nije dopušten zato što je delegaciju predložio sud koji na to (više) nije ovlašten, npr. prvostupanjski sud tijekom žalbenog postupka, ili sud koji je zatražio da se nadležnost prenese na njega sa suda koji je po zakonu nadležan; zatim, ako je predložena delegacija koja nije predviđena zakonom, npr. delegacija stvarne nadležnosti, delegacija suda koji bi odlučivao o reviziji, ${ }^{82}$

80 U ZS-u su općinski i županijski sudovi okvalificirani kao redovni sudovi, dok su trgovački sudovi i Visoki trgovački sudovi specijalizirani sudovi (14/1. ZS). Položaj Vrhovnog suda kao najvišeg suda nije posebno okvalificiran. Neovisno o tome, trebalo bi uzeti da je Vrhovni sud kao najviši sud i najviši sud za redovne sudove, budući da ne postoji poseban najviši redovni sud kao što je to propisano za trgovačke sudove kao specijalizirane sudove.

81 Za Visoki trgovački sud je izrijekom predviđeno da odlučuje o svrhovitoj delegaciji (24/2. ZS).

82 VSH: Gr-1/89, R-362/88 - PSP 41/92. Naime, o tom je pravnom lijeku isključivo funkcionalno nadležan odlučivati Vrhovni sud. 
delegacija za poduzimanje pojedine parnične radnje u postupku, ${ }^{83}$ itd. Ponovljeni ${ }^{84}$ prijedlog za delegaciju treba također odbaciti ako se okolnosti na kojima se temelji nisu bitno izmijenile - bila bi riječ o presuđenoj incidentalnoj stvari. $U$ istom bi sporu inače bilo moguće podnijeti i više sukcesivnih prijedloga za delegaciju - uz ispunjenje propisanih uvjeta.

Prigodom odlučivanja o prijedlogu trebalo bi voditi računa i o tome je li sud koji inicira delegaciju stvarno i mjesno nadležan te je li sud na koji treba prenijeti nadležnost stvarno nadležan. Naime, ako sud koji predlaže delegaciju nije (stvarno i/ ili mjesno) nadležan, otklanjanje nadležnosti i upućivanje predmeta nadležnom sudu, ako za to još uvijek postoje procesne mogućnosti, ako nije došlo do prekluzije tog prava, treba ostvarivati primjenom pravila o postupanju u slučaju nenadležnosti (arg. ex 17., 20., 21.), a ne o delegaciji nadležnosti.

Prijedlog za delegaciju treba prihvatiti ako se utvrdi da postoje za to zakonom propisani razlozi (v. supra ad 3.4.).

Prijedlog za delegaciju treba odbiti ako razlozi zbog kojih je ona zatražena, sami po sebi, ne opravdavaju, po ocjeni delegacijskog suda, da se ona odredi (nekonkluzivnost prijedloga s obzirom na razloge), odnosno ako nisu učinjeni dostatno vjerojatnima.

Prigodom ocjenjivanja osnovanosti prijedloga delegacijski sud treba uzeti u obzir i "stvarnu" nadležnost suda kojemu bi predmet trebalo delegirati. Naime, budući da postoje trgovački sudovi sužene, standardne i proširene nadležnosti (arg. ex 34.b ZPP, 7., 8. ZPSS, 43. ZA), Visoki trgovački sud bi nadležnost smio prenijeti samo na trgovački sud koji je po zakonu stvarno nadležan suditi u konkretnom sporu. Analogno treba postupiti i Vrhovni sud prigodom prenošenja nadležnosti s jednog na drugi županijski sud (arg. ex 34.a ZPP, 4., 5. ZPSS, 43. ZA, 219/2. ZR).

Delegacijski sud svoju odluku izravno dostavlja sudu koji je delegaciju predložio (arg. ex 398/1.).

\subsubsection{Isključenje pravnih lijekova}

Protiv rješenja o prijedlogu za delegaciju žalba nije dopuštena: prvo, stoga što je mogućnost žalbe protiv prvostupanjskih odluka Vrhovnoga suda posredno isključena time što uopće nije utvrđena (funkcionalna) nadležnost toga suda za odlučivanje o takvom pravnom lijeku protiv vlastitih prvostupanjskih odluka (arg. ex 34.d/1.), te zatim time što uopće nije predviđeno u kakvom bi sastavu on odlučivao u takvom slučaju (arg. ex 44., v.); drugo, per analogiam, arg. a cohaerentia, a completudine,

83 Naime, zahtjev za obavljanje pojedine pravne radnje može se izravno podnijeti za to nadležnom sudu kao zamoljenom sudu (224.). Uostalom pojedinu radnje može i nadležni sud obaviti na području drugog suda (25.).

84 Tako bi trebalo razumjeti i judikat (VSRH: Gr-1-262/02 - INF-N 5106/03.) donesen prije Novele 2003. kojom je reformiran institut svrhovite delegacije, prema kojemu bi sud koji je ovlašten odlučivati o delegaciji trebao odbaciti ponovni prijedlog stranke utemeljen na neizmijenjenim okolnostima. Naime, prije Novele 2003. o delegaciji se izravno odlučivalo i u povodu prijedloga stranke; nakon te novele sud pred kojim je postupak u tijeku odlučuje hoće li je u povodu prijedloga stranke zatražiti (68/1., 2.). 
zato što žalba nije dopuštena ni protiv prvostupanjskih odluka Vrhovnoga suda kad odlučuje o sukobu nadležnosti (arg. ex 24/3.).

\subsubsection{Postupak pred sudom koji je predložio delegaciju nakon donošenja odluke o prijedlogu}

Postupanje suda koji je delegaciju predložio nakon što mu se dostavi odluka o prijedlogu ovisi o sadržaju te odluke. U povodu negativne odluke, odluke o odbacivanju ili odbijanju prijedloga, taj je sud dužan nastaviti postupak, dok u povodu pozitivne odluke, predmet treba ustupiti sudu na koji je nadležnost prenesena - uz odgovarajuću primjenu pravila o postupanju u povodu pravomoćnog rješenja kojim se sudovi oglašavaju nenadležnima (21.). U svakom je slučaju dužan primjerak odluke dostaviti strankama.

\subsubsection{Postupak pred sudom na koji je nadležnost prenesena}

Sud na koji je nadležnost prenesena dužan je, u nedostatku posebnih odredaba o tome, postupiti kao kad mu predmet ustupi sud čija je nenadležnost pravomoćno utvrđena (22.). Pritom, budući da je sud koji odlučuje o delegaciji kao zajednički viši sud istodobno ovlašten rješavati i sukob o nadležnosti između suda čija je nadležnost prenesena i suda na koji je ona prenijeta, odnosno viši sud tom sudu, sud na koji je nadležnost prenesena vezan je tom odlukom. (Arg. per analogiam ex 22/3.)

Delegirani je sud ovlašten predložiti nužnu ili svrhovitu delegaciju ako se za to naknadno ispune uvjeti koji su propisani za te delegacije.

\subsection{Problem nenadležnosti delegiranog suda i izazivanje sukoba o nad- ležnosti}

U postupku pred delegiranim sudom mogao bi se po općim pravilima istaknuti prigovor apsolutne ili stvarne nenadležnosti. To bi osobito vrijedilo u slučaju u kojemu bi se o prijedlogu za delegaciju odlučilo bez prethodne konzultacije obiju stranaka. U načelu bi, ipak, trebalo uzeti da odluka o delegaciji implicira stav o postojanju i jurisdikcije hrvatskih sudova kao i stav da je delegirani sud stvarno nadležan, stav koji bi, svakako, po općim pravilima bilo moguće dovesti u pitanje.

\section{ORDINACIJA MJESNE NADLEŽNOSTI}

\subsection{Općenito}

Ordinacija mjesne nadležnosti ${ }^{85}$ je jedna od metoda određivanja mjesno nadležnog suda u pojedinom sporu, metoda kojoj se pribjegava kada je za suđenje nadležan sud u Republici Hrvatskoj, ali se prema pravilima o mjesnoj nadležnosti ${ }^{86}$ ne

85 O terminu ordinacija usp. TRIVA-DIKA, op. cit., 284.

86 Iako prema odredbi članka 69. ZPP ordinaciji treba pribjeći ako se prema odredbama ZPP-a ne može utvrditi koji je stvarno nadležni sud mjesno nadležan, mjesta primjeni ovog instituta ima 
može utvrditi koji je sud mjesno nadležan: u takvom slučaju Vrhovni sud Republike Hrvatske, na prijedlog stranke, određuje koji će stvarno nadležni sud biti mjesno nadležan (arg. ex 69.). Dakle, ordinacija mjesne nadležnosti jest određivanje mjesne nadležnosti od strane Vrhovnog suda Republike Hrvatske u pojedinom predmetu za suđenje u kojemu postoji jurisdikcija hrvatskih sudova, ali u kojemu se, na temelju pravila o mjesnoj nadležnosti, ne može utvrditi sud koji je mjesno nadležan (arg. ex 69.). ${ }^{87}$

Riječ je o još jednom podnormiranom institutu, što izaziva i čitav niz ozbiljnih pitanja pri njegovoj interpretaciji.

Ključno od tih pitanja tiče se pravozaštitnog cilja i s time povezanim učincima ordinacije. Pitanje je, naime, ima li ordinacija za cilj samo individualizirati sud kojem će se moći podnijeti tužba i u postupku pred kojim će se, zatim, po općim pravilima o tome, moći iznova otvoriti sva pitanja nadležnosti, ili je njezin pravozaštitni cilj definitivno riješiti pitanje jurisdikcije, stvarne i mjesne nadležnosti u pojedinom predmetu, barem s obzirom na početnu fazu postupka. Svaka od naznačenih solucija zahtijeva i odgovarajuće uređenje postupka u povodu prijedloga za ordinaciju i učinaka odluke koja bi se u njemu donijela. Jedno od daljnjih pitanja koje se nameću glede ovog instituta jest treba li uz prijedlog za ordinaciju priložiti i tužbu ili je odluku o tome prepuštena tužitelju. Povezano s ovim pitanjem jest i pitanje pravnih učinaka podnošenja prijedloga za ordinaciju uz koji tužba nije priložena, odnosno pitanje momenta na koji se u tom slučaju odnose pravni učinci pokretanja postupka pred sudom čija je mjesna nadležnost određena - je li to moment podnošenja prijedloga ili moment podnošenja tužbe ordiniranom sudu. Itd.

Praktično je značenje instituta ordinacije zapravo malo, na što ukazuje i relativno oskudna judikatura. Njegova će praktična važnost biti dodatno smanjena nakon stupanja na snagu novog Zakona o međunarodnom privatnom pravu (NN 101/17; ZMPP; v. i infra ad 4.2.2.3. $){ }^{88}$

\subsection{Pretpostavke za ordinaciju mjesne nadležnosti}

\subsubsection{Vrste pretpostavki}

Da bi Vrhovni sud ordinirao mjesnu nadležnost u određenom sporu, potrebno je da budu ispunjene dvije posebne kategorije pretpostavaka. O (pozitivnim i negativnim) pretpostavkama prve kategorije ovisi formiranje stava Vrhovnog suda o tome treba li uopće donijeti odluku o ordinaciji u konkretnom sporu, dok o pretpostavkama druge kategorije ovisi sam izbor stvarno nadležnog suda koji će biti mjesno nadležan.

Prvu kategoriju čine četiri pretpostavke, od kojih su tri kompetencijske meritorne pretpostavke, i to dvije pozitivne, a jedna negativna, dok je četvrta posebna pozitivna

samo onda kada se uopće na temelju pravila o mjesnoj nadležnosti, neovisno o tome u kojem se hrvatskom zakonu nalaze, ne može utvrditi koji je stvarno nadležni sud mjesno nadležan.

87 Ovaj institut nije izmijenjen nakon preuzimanja ZPP-a 1991., kada su riječi Vrhovni sud Jugoslavije zamijenjene riječima Vrhovni sud Hrvatske. Novelom iz 1992. je samo riječ

"stepen" zamijenjena riječju "stupanj".

88 ZMPP treba stupiti na snagu 29. siječnja 2019. 
procesna pretpostavka: 4.2.2.), ${ }^{89}$

(1) za suđenje u sporu treba biti nadležan sud u Republici Hrvatskoj (v. infra ad

(2) mora se znati sudovi koje su vrste i, eventualno, ranga za to stvarno nadležni (v. infra ad 4.2.3.),

(3) ne smije se moći na temelju pravila o mjesnoj nadležnosti utvrditi koji je sud mjesno nadležan (v. infra ad 4.2.4),

(4) tužitelj treba podnijeti prijedlog za ordinaciju (v. infra ad 4.2.5.).

Druga i treća navedena pretpostavka ove kategorije tiču se stvarne i mjesne nadležnosti prvostupanjskog suda. Do potreba za ordinacijom sudova višeg stupnja u pojedinom postupku ne može doći. Situacija u kojoj funkcionalno (stvarno i mjesno) nadležni drugostupanjski sud ne može postupati ne rješava se ordinacijom, već nužnom delegacijom nadležnosti (v. supra ad 2.6.).

Drugu kategoriju čine ove pretpostavke:

(1) sud čija će se nadležnost ordinirati treba biti stvarno nadležan (v. infra ad 4.2.3.1.),

(2) taj sud treba, prima facie, ispunjavati zahtjev da će suđenje obaviti pravično i u razumnom roku (v. infra ad 4.2.3.2.),

(3) njegov izbor treba obaviti slijedeći bitne pravnopolitičke zasade na kojima se temelje zakonska pravila o mjesnoj nadležnosti (v. infra ad 4.2.3.2.) - taj izbor ne smije biti izraz puke arbitrarnosti ordinacijskog suda ili se isključivo zasnivati na razlozima pravosudnog oportuniteta.

Pored navedenih pretpostavaka trebaju biti ispunjene i standardne procesne pretpostavke o kojima ovisi dopuštenost ordinacije.

\subsubsection{Pretpostavke o kojima ovisi odluka o potrebi ordinacije}

\subsubsection{Jurisdikcija}

Postojanje jurisdikcije hrvatskih sudova, prvu kompetencijsku meritornu pretpostavku za određivanje ordinacije, moguće je utvrditi na temelju pravila koja utvrđuju granice jurisdikcije tih sudova u parničnom postupku, posebno na temelju pravila o tzv. internoj jurisdikciji i/ili pravila o njihovoj međunarodnoj nadležnosti (27.).

Ustavnu osnovu za utvrđenje jurisdikcije hrvatskih sudova u građanskopravnim stvarima predstavlja odredba članka 29. stavka 1. URH, koja svakome jamči pravo da zakonom ustanovljeni neovisni i nepristrani sud pravično i u razumnom roku odluči, uz ostalo, o njegovim pravima i obvezama. Ova je odredba razrađena odredbom članka 3. stavka 2. ZS, prema kojoj sudovi, uz ostalo, odlučuju u sporovima o temeljnim pravima i obvezama čovjeka, o pravima i obvezama Republike Hrvatske i jedinica lokalne i područne (regionalne) samouprave te o pravima i obvezama drugih pravnih osoba, rješavaju sporove o osobnim odnosima građana, radne, trgovačke, imovinske i druge građanskopravne sporove te odlučuju u drugim pravnim stvarima kad je to 
zakonom određeno. Ta je odredba primjerena parničnom postupku odredbom članka 1. ZPP, koja propisuje da se tim zakonom uređuju pravila postupka na temelju kojih sud raspravlja i odlučuje u sporovima o osnovnim pravima i obvezama čovjeka i građanina, o osobnim i obiteljskim odnosima građana te u radnim, trgovačkim, imovinskim i drugim građanskopravnim sporovima, ako zakonom nije za neke od tih sporova određeno da u njima sud rješava po pravilima kojega drugog postupka. Granice jurisdikcije hrvatskih sudova u parničnom postupku, postavljene navedenom odredbom članka 1. ZPP, dopunski su razrađene pravilima toga zakona o stvarnoj nadležnosti sudova u tom postupku (34.-34d.), a svakako i pravima drugih zakona o takvoj nadležnosti. U sporovima s međunarodnim obilježjem za utvrđivanja granica jurisdikcije hrvatskih sudova mjerodavne su odredbe drugih domaćih zakona i međunarodnih sporazuma o međunarodnoj nadležnosti hrvatskih sudova, ali i norme odgovarajućih akata Europske unije.

\subsubsection{Stvarna nadležnost}

Utvrđenje sudovi koje su vrste i, eventualno, ranga stvarno nadležni suditi u prvom stupnju u konkretnom sporu (druga kompetencijska meritorna pretpostavka iz prve kategorije pretpostavki za određivanje ordinacije - v. supra ad 4.2.1.) je važno zato što o vrsti sudova koji su stvarno nadležni u prvom stupnju može ovisiti provjera je li ispunjena i treća, negativna, kompetencijska meritorna pretpostavka za određivanje ordinacije - da na temelju pravila o mjesnoj nadležnosti nije moguće utvrditi koji je od stvarno nadležnih sudova mjesno nadležan (v. supra ad 4.2.1.). Naime, pravila o mjesnoj nadležnosti sudova u parničnom postupku pred trgovačkim sudovima mogu se djelomično razlikovati od onih koja vrijede za određivanje mjesne nadležnosti u parničnom postupku pred općinskim sudovima itd. (arg., inter alia, ex 492.), pa zato u kauzalno istovrsnom sporu mogućnost utvrđenja mjesne nadležnosti može ovisiti o tome sudovi koje su vrste stvarno nadležni.

U slučajevima u kojima postoji jurisdikcija hrvatskih sudova, stvarno se nadležni sud može uvijek utvrditi: ako se po pravilima o stvarnoj nadležnosti ne može utvrditi koji je sud određne vrste i ranga stvarno nadležan, nadležan će biti općinski sud kao opće stvarno nadležan ( $\arg$. ex 34/2. ZS).

\subsubsection{Nemogućnost da se utvrdi sud koji je mjesno nadležan}

Treća, negativna, kompetencijska meritorna pretpostavka za donošenje odluke o potrebi ordinacije, dakle, da se na temelju zakonskih pravila o mjesnoj nadležnosti ne može utvrditi koji je od stvarno nadležnih sudova mjesno nadležan, može biti ispunjena u slučajevima u kojima za određeni spor ne bi postojala posebna pravila o mjesnoj nadležnosti, odnosno, ako bi i postojala, da se ne bi mogla primijeniti na konkretni spor, a mjesno se nadležni sud ne bi mogao utvrditi ni po pravilima o općoj mjesnoj nadležnosti. ${ }^{90}$ Naznačena bi nepodudarnost kriterija za utvrđivanje međunarodne i

90 Jedan od primjera u kojemu bi moglo doći do potrebe za ordinacijom mjesne nadležnosti ticao bi se zasnivanje nadležnosti hrvatskih sudova za tzv. materijalne suparničare (196/1.1. 
mjesne nadležnosti mogla biti prevladana nakon što stupi na snagu ZMPP. Naime, prema odredbi članka 59. ZMPP, ako se mjesna nadležnost suda Republike Hrvatske neće moći zasnovati primjenom posebnih zakona, ona će se određivati odgovarajućom primjenom odredaba ZMPP-a o međunarodnoj nadležnosti, a ako se mjesna nadležnost ni tako neće moći zasnovati, mjesno će biti nadležan sud u Zagrebu. ${ }^{91}$

\subsubsection{Prijedlog za ordinaciju}

Pozitivna procesna pretpostavka za donošenje odluke o tome je li potrebna ordinacija jest prijedlog potencijalnog tužitelja Vrhovnom sudu da donese takvu odluku. O ordinaciji se, naime, ne odlučuje po službenoj dužnosti.

O sadržaju prijedloga i mogućnosti da uz njega bude podnesena i tužba v. infra ad 4.3.1.-3.3.

\subsubsection{Dopunske pretpostavke za ordiniranje određenog suda}

\subsubsection{Formalna pretpostavka}

Jedina dopunska formalna pretpostavka koja treba biti ispunjena prigodom individualiziranja suda čija će se nadležnost ordinirati jest da taj sud bude stvarno nadležan. Inzistiranje na ovoj pretpostavci je osobito važno u onim slučajevima u kojima postoje sudovi nominalno iste vrste i ranga ali različite stvarne nadležnosti. Zato Vrhovni sud prigodom ordinacije trgovačkog suda koji će biti mjesno nadležan u

ZPP). Naime, međunarodna nadležnost hrvatskih sudova za materijalne suparničare postoji i kad jedan od tuženika ima prebivalište odnosno sjedište u Republici Hrvatskoj (46/4. Zakona o rješavanju sukoba zakona s propisima drugih zemalja u određenim odnosima, NN 53/91, 88/01; ZRSZ). Pritom nije bitno nalaze li se oni međusobno u odnosu glavnih ili sporednih obveznika - u svim slučajevima materijalnog suparničarstva dolazi do atrakcije međunarodne nadležnosti hrvatskih sudova čim takva opća nadležnost hrvatskih sudova postoji za jednog od njih. To znači da bi se međunarodna nadležnost hrvatskih sudova mogla zasnovati i za glavne suobveznike zato što postoji za kojeg od sporednih. Budući da u tom slučaju ne bi za glavne suobveznike moglo doći i do atrakcije mjesne nadležnosti suda koji je tako nadležan za nekog od sporednih (arg. ex 50/1. ZPP), tužitelj bi, da bi pred sudom koji je mjesno nadležan za tog sporednog suobveznika mogao tužiti i glavne, morao zatražiti od Vrhovnog suda da ordinira nadležnost toga suda (69.). Opisana je situacija posljedica okolnosti da međunarodna i mjesna nadležnost nisu određene prema simetričnim atrakcijskim kriterijima. Zbog takve nepodudarnosti potreba za ordinacijom može nastati u bračnim sporovima (61., 63. ZRSZ, 54. ZPP), u sporovima za utvrđivanje ili osporavanje očinstva ili majčinstva (64. ZRSZ, 55. ZPP), itd. U jednom izvanparničnom predmetu radi proglašenja nestale osobe za umrlu suđeno je da zahtjev za ordinaciju nije osnovan zbog nedostatka jurisdikcije jer osobe čije se proglašenje za umrlu traži nije na području Republike Hrvatske imao svoje prebivalište niti je bio njezin državljanin, a nije umro na njezinom teritoriju (78/1., 2. ZRSZ) (VSRH: Gr. Broj: Gr1 383/082 od 18. prosinca 2008.). U jednom sličnom slučaju i VSRH: Gr1 382/08-2 od 27. studenoga 2008. U jednom ovršnom predmetu odbijen je prijedlog za ordinaciju jer je ocijenjeno da se na temelju pravila o određivanju mjesno nadležnog suda može utvrditi koji je sud mjesno nadležan (VSRH: Broj: Gr1-127/12-2 od 29. ožujka 2012.).

91 Treba primijetiti da zakonopisci ZMPP-u nisu uzeli u obzir okolnost da u Zagrebu postoje tri općinska suda (arg. ex 2/XII., XV. ZPSS). 
određenom pomorskom sporu mora voditi računa o tome da to bude jedan od četiriju trgovačkih sudova koji su nadležni za rješavanje takvih sporova, dakle, izabrati između trgovačkih sudova u Osijeku, Rijeci, Splitu i Zagrebu (arg. ex 8. ZPSS).

\subsubsection{Materijalni kriteriji za izbor suda čija će se mjesna nadležnost ordinirati}

Prigodom opredjeljenja između više potencijalno mjesno nadležnih sudova iste stvarne nadležnosti treba voditi računa i o tome da izabrani sud, s jedne strane, prima facie, jamči da će se suđenje obaviti pravično i u razumnom roku (arg. ex 29/1. URH, 4/2. ZS, 10/1. ZPP), a, s druge strane, da njegov izbor bude obavljan slijedeći bitne pravnopolitičke zasade na kojima se temelje zakonska pravila o mjesnoj nadležnosti, voditi računa i o tome da taj izbor ne smije biti izraz puke arbitrarnosti ili se zasnivati na razlozima pukog pravosudnog oportuniteta. To znači da prigodom donošenja odluke o ordinaciji treba uzeti, između ostaloga, u obzir vrstu spora (u subjektivnom, objektivnom i vrijednosnom smislu) te ocijeniti koji bi od kriterija impliciranih u zakonskim pravilima o mjesnoj nadležnosti bili što primjereniji za obavljanje tog izbora u konkretnom slučaju. Kao orijentir bi, međutim, svakako mogli poslužiti i kriteriji propisani za svrhovitu delegaciju: ordinirani sud treba biti sud koji će (očito) (naj)lakše provesti postupak ili sud za čije ordiniranje postoje drugi važni razlozi (arg. ex 68/1., v. supra ad 2.4.): ordinacija je zapravo jedan specifični oblik delegacije nadležnosti. ${ }^{92}$

Razlika prema nužnoj i svrhovitoj delegaciji bila bi u tome što se kod te dvije delegacije znade koji je sud mjesno nadležan, ali se iz odgovarajućih razloga mjesna nadležnost prenosi s tog suda na drugi sud, dok se kod ordinacije znade da postoji jurisdikcija hrvatskih sudova pa se, zato što se na temelju zakonskih pravila o mjesnoj nadležnosti ne može utvrditi koji je od stvarno nadležnih sudova mjesno nadležan u pojedinom slučaju, između svih potencijalno mjesno nadležnih određuje onaj kojemu će takva nadležnost biti povjerena.

\subsection{Ordinacijski postupak}

\subsubsection{Prijedlog za ordinaciju}

Postupak za ordinaciju mjesne nadležnosti pokreće se prijedlogom "stranke" (69.), po prirodi stvari, potencijalnog tužitelja, ako uz prijedlog za ordinaciju tužba nije podnesena, odnosno tužitelja ako je to učinjeno. Smisao je, naime, ordinacije da se odredi koji će od stvarno nadležnih sudova biti mjesno nadležan za konkretni spor kako bi se tom sudu tužbu mogla podnijeti (proslijediti).

Pored onoga što treba sadržavati svaki podnesak (106.), u prijedlogu treba supstancirati sam spor uključujući i pravnu zaštitu koja se namjerava tražiti (ili traži u priloženoj tužbi) pred sudom čija će se mjesna nadležnost ordinirati. Zatim bi

92 To bi odgovaralo i dvojakom značenju riječi delegacija, delegiranje, delegirati kao prenošenja nečega s nekoga na nekog drugog, ali i kao davanje ovlasti nekome za nešto. Usp.: KLAIĆ, Rječnik stranih riječi, 1990., 271., 272.; Rječnik hrvatskog jezika, Leksikografskog zavoda Miroslav Krleža i Školske knjige, 2000., 166. 
trebalo supstancirano ustvrditi da postoji nadležnost hrvatskih sudova za suđenje u konkretnom sporu, da su za to stvarno nadležni sudovi određene vrste i ranga, ali da se na temelju pravila o mjesnoj nadležnosti ne može utvrditi koji bi od tih sudova bio mjesno nadležan. U prijedlogu je dovoljno uopćeno zatražiti da Vrhovni sud odredi stvarno nadležni sud koji će biti mjesno nadležan. U prijedlogu se može naznačiti sud koji bi trebalo ordinirati kao mjesno nadležni sud, ali ordinacijski sud nije vezan takvim prijedlogom. Prijedlog bi trebao biti potkrijepljen i odgovarajućim (likvidnim) dokazima - o tome bi mogla ovisiti ocjena o njegovoj osnovanosti.

Prijedlog za ordinaciju se izravno podnosi Vrhovnom sudu (arg. ex 68.) jer stranka koja ga podnosi ne zna kojem bi prvostupanjskom sudu mogla podnijeti tužbu.

\subsubsection{Podnošenje tužbe uz prijedlog za ordinaciju}

U Zakonu nije izrijekom riješeno pitanje treba li tužitelj uz prijedlog podnijeti i tužbu.

U teoriji je izražen stav da bi se tužba podnosila tek nakon što bi potencijalni tužitelj primio rješenje o ordinaciji jer da se prije toga ne zna kojem bi je sudu trebalo podnijeti. ${ }^{93}$ Međutim, u prilog stavu da bi tužbu trebalo priložiti već uz prijedlog za ordinaciju, pored pragmatičnog razloga da se Vrhovni sud može najbolje upoznati s prirodom spora u vezi s kojim treba odlučiti o tom prijedlogu tek ako raspolaže tužbom kojom se pokreće postupak za rješenje toga spora (činjenično i pravno supstanciranu, s određenim tužbenim zahtjevom), govore i drugi nezanemarivi razlozi. Prvo, samo ako se tužba podnese uz prijedlog za ordinaciju, moći će se prigodom odlučivanja o tom prijedlogu primijeniti pravilo da se nadležnost ocjenjuje na temelju navoda u tužbi i činjenica koje su sudu poznate (15/2.), jer Vrhovni sud s obzirom na okolnosti koje postoje u tom momentu treba, odlučujući o tom prijedlogu, utvrditi postoji li jurisdikcija domaćih sudova te, ako nađe da postoji, može li se ili ne može na temelju pravila o mjesnoj nadležnosti utvrditi koji je od stvarno nadležnih sudova mjesno nadležan. Drugo, time se omogućava potencijalnom tužitelju da pravodobnim pokretanjem postupka izazove pravne posljedice koje se uz to vežu. Naime, ako bi tužitelj morao čekati da Vrhovni sud odluči o njegovu prijedlogu i tek onda podnijeti tužbu ordiniranom sudu, mogle bi ga pogoditi štetne posljedice prekluzije prava na podnošenje tužbe (282/2.), zastare, itd. ${ }^{44}$ Treće, samo tako će biti moguće ostvariti koincidenciju kompetencijsko relevantnog činjeničnog stanja za odlučivanje o prijedlogu za ordinaciju i za ocjenu o postojanju uvjeta za zasnivanje mjesne nadležnosti određenog stvarno nadležnog suda. Budući da su za ocjenu nadležnosti (u pravilu) mjerodavne okolnosti koje su postojale u vrijeme podnošenja tužbe sudu (arg. ex 15/3.) (perpetuatio fori), Vrhovni sud, odlučujući o prijedlogu za ordinaciju, mora moći provjeriti postoje li pretpostavaka za jurisdikciju, stvarnu

93 Usp. TRIVA-DIKA, GPPP, 284.

94 Tužitelj ne bi smio biti izložen riziku da snosi štetne posljedice okolnosti da mu zakonska pravila o nadležnosti ne omogućavaju da utvrdi sud kome će podnijeti tužbu. Sve ovo svakako uz pretpostavku da se, ako se prihvati kritizirano shvaćanje, ne prihvati i stajalište da bi se u takvim slučajevima smatralo da je postupak pokrenut podnošenjem zahtjeva za ordinaciju, za što, međutim, nema određenog uporišta u Zakonu (v., međutim, infra ad 4.3.3.). 
i mjesnu nadležnost s obzirom na isti moment s obzirom na koji se one općenito utvrđuju u postupku.

U tužbi koju bi tužitelj priložio uz prijedlog za ordinaciju po prirodi stvari ne bi mogao biti individualiziran sud koji bi bio mjesno nadležan za suđenje u prvom stupnju. Njega bi svojim rješenjem individualizirao Vrhovni sud.

Podnošenjem tužbe ordinacijskom sudu uz prijedlog za ordinaciju pokretao bi se i parnični postupak u konkretnoj pravnoj stvari (arg. ex 185.). Uz takvo bi se podnošenje tužbe vezali i svi učinci njezina podnošenja.

Ako Vrhovni sud prihvati prijedlog i donese rješenje o ordinaciji, ordiniranom bi sudu kao mjesno nadležnom trebao proslijediti primljenu tužbu. Ako bi utvrdio da se može utvrditi sud koji je mjesno nadležan, trebao bi odbiti prijedlog za ordinaciju, ako tužba ne bi bila priložena uz taj prijedlog, ili odbiti prijedlog za ordinaciju i tužbu proslijediti sudu koji je mjesno nadležan ili jednom od elektivno nadležnih sudova. Trebalo bi, naime, uzeti da prijedlog za ordinaciju ovlašćuje Vrhovni sud i za izbor između više elektivno (konkurentno) mjesno nadležnih sudova.

\subsubsection{Učinci prijedloga uz koji tužba nije priložena}

Ako se prihvati stajalište da se tužba ne treba podnijeti uz prijedlog za ordinaciju, već da će o dispoziciji tužitelja ovisiti hoće li je i kada naknadno podnijeti ordiniranom sudu, bilo bi nužno odgovoriti na pitanje kakvi bi u tom slučaju bili učinci podnošenja prijedloga za ordinaciju, ali i na pitanje kad bi se u takvom slučaju smatralo da je postupak pokrenut i da su nastupili i koji pravni učinci njegova pokretanja - u momentu podnošenja prijedloga za ordinaciju, u momentu donošenja rješenja o ordinaciji ili u momentu podnošenja tužbe. Ako se prihvati stav da bi se i razmatranom slučaju postupak pokretao tek naknadnim podnošenjem tužbe, u načelu bi tek tim momentom nastupale pravne posljedice njenog podnošenja, između ostaloga i prekid raznih prekluzivnih i zastarnih rokova. Taj bi moment trebao biti relevantan i za naknadno prosuđivanje nadležnosti, apsolutne, stvarne i mjesne, jer bi se odluka kojom je ordinacija određena odnosila na podnošenju tužbe prethodećem momentu, između kojeg bi momenta i momenta podnošenja tužbe moglo proteći dosta vremena. ${ }^{95}$ Ako se, međutim, prihvati stav da bi se uz podnošenje prijedloga za ordinaciju vezali pravni učinci pokretanja postupka, zapravo učinci podnošenja tužbe, do kojeg bi se stava dolazilo generalizacijom pravila po kojemu se zastara prekidala "svakom drugom vjerovnikovom radnjom poduzetom protiv dužnika pred sudom (...) radi utvrđivanja, osiguranja ili ostvarivanja tražbine” (241. ZOO), stava koji bi implicirao da prijedlog za ordinaciju ima značenje takve radnje, tada bi morali pristati

95 Upravo se zato, ako se prihvati stav da tužbu ne bi trebalo podnositi uz prijedloga za ordinaciju, moglo postaviti pitanje o roku u kojemu bi nakon donošenja odluke o ordiniranju mjesno nadležnog suda trebalo tom sudu podnijeti tužbu. Naime, stav da bi jednom ordinirani sud "zauvijek" bio mjesno nadležan protivio bi se realitetu da se nadležnost prosuđuje i određuje s obzirom na određeni moment u razvitku odnosa pravnih subjekata, ali i "života pravnog poretka". Naime, nakon što bi mjesno nadležan sud bio ordiniran mogli bi se izmijeniti zakoni s obzirom na koje je odlučeno o prijedlogu za ordinaciju, pa bi se zato moglo iznova postaviti pitanje o opravdanosti ordinacije. 
ne samo na to da je podnošenjem toga prijedloga došlo do prekida tijeka prekluzivnih i zastarnih rokova, već i da je postupak općenito pokrenut, čije će aktualiziranje, ipak, ovisiti o tome hoće li i kada tužitelj zaista podnijeti tužbu. Takvo bi rješenje svakako zahtijevalo da se na odgovarajući način njemu primjeri i pravni položaj tuženika - i on bi se morao moći koristiti posljedicama stava da bi se smatralo da je postupak pokrenut podnošenjem prijedloga za ordinaciju, i njemu bi trebalo dopustiti da u povodu takva prijedloga, osobito ako bi mu se dostavio radi očitovanja (v. infra ad 4.3.4.), postupi kao u povodu tužbe koja mu je dostavljena na odgovor - barem u pogledu pitanja jesu li ispunjene pretpostavke za ordinaciju. ${ }^{96}$

Ako bi se zauzeo stav da bi se uz prijedlog za ordinaciju vezali (neki) pravni učinci podnošenja tužbe sudu, trebalo bi zauzeti i stav o tome u kojem bi roku tužitelj trebao podnijeti tužbu nakon što bi mu bilo dostavljeno rješenje kojom bi ordinacija bila određena. Trebalo bi, čini se, zauzeti stav da bi to bio dužan učiniti u roku od najkasnije tri mjeseca (arg. per analogiam, a cohaerentia ex 242., 243. ZOO). ${ }^{97}$

Svi naznačeni problemi ne bi se nametali ako bi se prihvatio stav da bi tužitelj uz prijedlog za ordinaciju bio dužan podnijeti i tužbu. Prihvaćanjem takva stava uspostavila bi se bitna ravnoteža pravne pozicije tužitelja i tuženika u postupku u kojemu treba ordinirati mjesnu nadležnost.

\subsubsection{Kontradiktornost ordinacijskog postupka}

U Zakonu nije izrijekom riješeno pitanje treba li prijedlog za ordinaciju, prije nego što se o njemu odluči, dostaviti potencijalnom tuženiku na odgovor. Zbog toga bi glede toga trebalo postupiti po općim pravilima, što će, opet, ovisiti o stavu koji će se zauzeti o tome treba li uz prijedlog za ordinaciju priložiti i tužbu, odnosno, ako je ne treba priložiti, kakvi bi bili učinci odluke o ordinaciji.

U načelu, prije donošenja odluke o prijedlogu za ordinaciju, protivnoj bi stranci trebalo omogućiti da se o njemu izjasni (5/2.) - dostavom prijedloga zajedno s tužbom s pozivom da se očituje samo o prijedlogu za ordinaciju, odnosno dostavom samo

96 Ako bi se tuženiku prijedlog za ordinaciju koji bi se smatrao aktom kojim se postupak pokreće dostavljao radi očitovanja u pogledu postojanja pretpostavaka za ordinaciju, očitovanja koje bi imalo značenje ograničenog odgovora na tužbu, trebalo bi uzeti da bi dostavom tog prijedloga tuženiku nastupale i pravne posljedice litispendecije (194/1.). Kad je riječ o ograničenosti očitovanja tuženika o kojemu je riječ, tuženika se ne bi smjelo moći ograničiti da u njemu iznosi i meritorno relevantne momente koje bi mogao iznositi u "pravom" odgovoru na tužbu - u mjeri u kojoj bi o tim momentima ovisilo donošenje odluke o prijedlogu. U tom bi smislu to očitovanje moglo sadržajno odgovarati pravom odgovoru na tužbu, sa svim relevantnim posljedicama davanja takva odgovora. Upravo se stoga postavlja i pitanje bi li i tuženik mogao u povodu prijedloga za ordinaciju koji mu je dostavljen radi očitovanja podnijeti svoj prijedlog za ordinaciju nadležnosti istog suda za eventualnu protutužbu, uz koji bi se prijedlog vezale sve pravne posljedice podnošenja takve protutužbe (189.).

97 Naime, ako tužba protiv dužnika bude odbačena zbog nenadležnosti suda ili kojega drugog uzroka koji se ne tiče biti stvari, pa vjerovnik ponovno podnese tužbu u roku od tri mjeseca od dana pravomoćnosti odluke o odbacivanju tužbe, smatra se da je zastara prekinuta prvom tužbom (243/1. ZOO), a isto vrijedi i za pozivanje u zaštitu, i za isticanje prijeboja tražbine u sporu te u slučaju kad je sud ili drugo tijelo uputilo dužnika da svoju prijavljenu tražbinu ostvaruje u parničnom postupku (243/2. ZOO). 
prijedloga, ako uz njega tužba ne bi bila priložena. Naime, odlukom o ordinaciji ne rješava se samo pitanje jurisdikcije hrvatskih sudova, već i pitanje koji je sud u konkretnom sporu stvarno i mjesno nadležan. Ako bi tuženika vezala takva odluka u smislu da više ne bi mogao dovoditi u pitanje postojanje jurisdikcije hrvatskih sudova te stvarnu i mjesnu nadležnost ordiniranog suda, on bi naknadno tijekom postupka mogao istaknuti prigovor nenadležnosti samo iz razloga koji bi se temeljili na okolnostima koje bi nastale nakon momenta s obzirom na koji bi se ocjenjivala nadležnost prigodom donošenja odluke o ordinaciji. Ako mu se ne bi omogućilo da se očituje o prijedlogu za ordinaciju, bilo bi povrijeđeno njegovo pravo na saslušanje u postupku, na pravično suđenje, pravo na suca čija bi nadležnost bila utvrđena $u$ skladu sa zakonom. Ako bi se zauzeo stav da ex parte donesena odluka o ordinaciji ne prekludira tuženika da u nastavljenom postupku, u skladu s općim pravilima o tome, iznosi sve one prigovore nenadležnosti koje inače može iznositi u postupku nakon što mu je tužba dostavljena na odgovor, dakle i prigovor nepostojanja jurisdikcije hrvatskih sudova te prigovor stvarne i mjesne nenadležnosti ordiniranog suda, ordinacija bi izgubila svaki smisao osim onoga da je potrebna samo zato da bi se odredio sud kojemu bi tužitelj mogao podnijeti tužbu, sud za koji bi se naknadno, u povodu prigovora tuženika, moglo pokazati da nije nadležan zato što nema jurisdikcije hrvatskih sudova, da nije stvarno nadležan ili da nije ni mjesno nadležan jer su se stvarna i mjesna nadležnost mogle utvrditi na temelju zakona.

Iznimno, u slučajevima u kojima bi već na temelju samog prijedloga mogao donijeti odluku o odbacivanju ili odbijanju prijedloga za ordinaciju, Vrhovni sud ne bi trebao prijedlog, eventualno s priloženom tužbom, dostaviti protivnoj stranci.

Zato se čini da bi, između ostaloga, s jedne strane, načela ekonomičnosti, koncentracije i efikasnosti u postupanju te pravne sigurnosti, a s druge strane, načelo saslušanja stranaka kao aspekt zahtjeva da svakoj stranci treba osigurati ostvarivanje prava na pravično suđenje, zahtijevala da se prije donošenja odluke o prijedlogu za ordinaciju omogući (potencijalnom) tuženiku da se očituje o tome prijedlogu. Nakon toga, tuženik bi u nastavljenom postupku bio prekludiran u iznošenju prigovora nenadležnosti - s obzirom na moment s obzirom na koji bi se odnosila odluka o ordinaciji.

Prigodom očitovanja o prijedlogu za ordinaciju tuženik bi se trebao pozvati i na postojanje sporazuma o prorogaciji, u smislu da bi nakon donošenja odluke o ordinaciji gubio pravo da se u nastavljenom postupku poziva na taj sporazum.

I u ordinacijskom bi postupku trebalo vrijediti načela pomoći neukoj stranci (11.) i otvorenog pravosuđenja (5., 7., 219., 220., 288.a/2.), ali i opća pravila o postupanju s nerazumljivim i nepotpunim podnescima (109.).

Potreba za ordinacijom u naznačenom smislu bi prestala nakon stupanja na snagu novog ZMPP-a, jer bi se uvijek znalo koji je sud mjesno nadležan ako se na temelju pravila o mjesnoj nadležnosti on ne bi mogao utvrditi - to bi bio stvarno nadležni sud u Zagrebu (v. supra ad 4.2.2.3. in fine). 


\subsubsection{Odlučivanje}

\subsubsection{Funcionalna nadležnost $i$ sastav ordinacijskog suda}

O prijedlogu za ordinaciju odlučuje Vrhovni sud (69.).

Iako u Zakonu nije izrijekom propisano u kojem sastavu Vrhovni sud odlučuje o ordinaciji (arg. ex 44., 69.), treba uzeti da o ordinaciji odlučuje sudac pojedinac toga suda. Na takav stav upućuje, arg. per analogiam, a cohaerentia, odredba članka 68. stavka 3. ZPP, po kojom o tzv. svrhovitoj delegaciji odlučuje sudac pojedinac najvišeg suda određene vrste, dakle i Vrhovni sud kad nastupa u toj funkciji. Naime, budući da je ordinacija nadležnosti u širem smislu također svojevrsna delegacija nadležnosti, za sve bi slučajeve u kojima najviši sud određuje nadležnost nižih sudova trebala vrijediti odgovarajuća pravila. ${ }^{98}$

\subsubsection{Prethodno ispitivanje prijedloga za ordinaciju}

Pošto primi prijedlog, Vrhovni bi sud najprije trebao ispitati je li on dopušten.

U povodu nerazumljivog i/ili nepotpunog prijedloga trebalo bi postupiti kao u povodu svakog drugog podneska s takvim nedostacima (106.-109.).

Prijedlog ne bi bio dopušten ako ne bi bile ispunjene pozitivne odnosno ako bi postojale negativne procesne pretpostavke o kojima bi ovisila dopuštenost svakog inicijalnog akta stranaka u parničnom postupku. ${ }^{99}$ Treba uzeti da bi Vrhovni sud u načelu bio dužan poduzeti potrebne radnje radi otklanjanja otklonjivih nedostataka zbog kojih prijedlog ne bi bio dopušten (arg. ex 109., 291.). Prijedlog ne bi bio dopušten ni ako bi se na temelju onoga što je u njemu izneseno moglo zaključiti da su protekli prekluzivni rokovi u kojima se tužba trebala podnijeti sudu čija se ordinacija traži. Isto bi vrijedilo i ako prethodno ne bi bio proveden propisani postupak za izvansudsko rješenje spora ( $\arg$. ex 282.).

Ako bi tužba bila podnesena uz prijedlog, eventualni nedostaci zbog kojih bi ona bila nedopuštena, a koji bi se mogli otkloniti u postupku pred sudom koji bi bio ordiniran, ne bi trebali priječiti donošenje meritorne odluke o prijedlogu. $\mathrm{O}$ dopuštenosti tužbe s naznačenim nedostacima odlučivalo bi se postupku pred prvostupanjskim sudom.

\subsubsection{Prikupljanje procesnog materijala za donošenje odluke}

Vrhovni sud svoju odluku o prijedlogu za ordinaciju može zasnovati na navodima u tom prijedlogu, eventualno na navodima iz priložene tužbe, (likvidnim) dokazima, u pravilu ispravama, koji su priloženi uz prijedlog i priloženu tužbu, zatim

98 U prilog takvom rješenje govorila bi i okolnost da je Novelom 2003. institut svrhovite delegacije (68.) reformiran, između ostaloga i na način da je izrijekom propisana nadležnost suca pojedinca najvišeg suda određene vrste za odlučivanje o toj delegaciji, dok je to propušteno učiniti i u odnosu na institut ordinacije nadležnosti (69.), koji je ostao i dalje podnormiran.

99 O pojmu procesnih pretpostavki usp. TRIVA-DIKA, GPPP, § 6., DIKA, Građansko parnično pravo, VII., § 31., 32. 
na navodima i možebitnim (likvidnim) dokazima iz očitovanja protivne stranke o prijedlogu, ali i na onome što bi naknadno pribavio od stranaka ili državnih tijela, npr. nižih sudova tijekom ordinacijskog postupka. Naime, Vrhovni sud, provodeći incidentalni ordinacijski postupak, ne nastupa kao najviša sudbena instancija u određenom postupku, već kao sud koji u prvom i posljednjem stupnju odlučuje o određenom pravnom pitanju o rješenju kojega ovisi mogućnost pokretanja i provedbe određenog postupaka.

\subsubsection{Vezanost prijedlogom i meritorna odluka}

U načelu Vrhovni sud, odlučujući o prijedlogu za ordinaciju, treba odlučivati u granicama toga prijedloga. ${ }^{100}$ To znači da je taj sud pri donošenju svoje odluke vezan za određenje spora u prijedlogu, ali i zahtjevom za ordinaciju sadržanom u tom prijedlogu u smislu da ne smije suditi preko i mimo toga zahtjeva. Upravo stoga i odluke koje Vrhovni sud može donijeti u povodu prijedloga ovise o onome što je njime in concreto zatraženo.

Ako utvrdi da za suđenje u konkretnom sporu ne postoji nadležnost sudova u Republici Hrvatskoj, prijedlog za ordinaciju treba odbiti. Taj prijedlog treba odbiti i ako se na temelju propisa o mjesnoj nadležnosti može utvrditi koji je sud mjesno nadležan.

Ako je prijedlogom za ordinaciju od njega zatraženo da sam odredi koji će od sudova u Republici Hrvatskoj biti stvarno i mjesno nadležan, Vrhovni sud je to ovlašten učiniti, svakako uz uvjet da utvrdi da postoji nadležnost tih sudova.

Ako predlagatelj zatraži da se ordinira mjesna nadležnost suda određene vrste $i$ ranga, takav prijedlog treba odbiti ako Vrhovni sud ocijeni da za suđenje u konkretnom sporu nisu stvarno nadležni sudovi te vrste i ranga, svakako uz uvjet da predlagatelj (ako se uopće prihvati stav da tome ima mjesta u ordinacijskom postupku), nakon upute koju glede toga dobije od Vrhovnog suda (arg. ex 109.), ne ispravi prijedlog. ${ }^{101}$ Stvarna nadležnost suda čiju mjesnu nadležnost treba ordinirati je jedna od meritornih pretpostavaka za prihvaćanje prijedloga (v. supra ad 4.2.2.).

Ako je u prijedlogu za ordinaciju individualiziran sud koji bi trebalo odrediti kao mjesno nadležni sud, Vrhovni je sud dužan odbiti takav prijedlog ako ocijeni da, unatoč tome što su ispunjene pretpostavke za ordinaciju (v. supra ad 4.2.2.), nisu ispunjene pretpostavke za ordinaciju predloženog suda (v. supra ad 4.2.3.). U prijedlogu zapravo ne treba indivudalizirati sud čiju se mjesnu nadležnost treba ordinirati - koji će od stvarno nadležnih sudova biti in concreto mjesno nadležan određuje Vrhovni sud uzimajući u obzir okolnosti navedene u prijedlogu za ordinaciju i u, eventualnom, očitovanju protivne stranke te na temelju rezultata izviđaja koje bi eventualno proveo.

100 Naime, u parničnom postupku sud (u pravilu) odlučuje u granicama zahtjeva koji su stavljeni u postupku (2/1.). Budući da se u navedenoj odredbi općenito govori o zahtjevima koji se stavljaju u postupku, a ne samo o tužbenom zahtjevu ili, eventualno, o još nekim zahtjevima, valja uzeti da bi to trebalo vrijediti i za ordinacijski zahtjev.

101 Nakon što bi takav njezin prijedlog bio odbijen, stranka bi mogla podnijeti novi prijedlog u kojemu bi naznačila sud druge vrste i/ili ranga čiju bi mjesnu nadležnost trebalo delegirati. 
Vrhovni sud će prijedlog prihvatiti ako utvrdi da su ispunjene pretpostavke za ordinaciju (v. supra ad 4.2.2.). U tom slučaju, uzimajući u obzir pretpostavke o kojima ovisi individualiziranje stvarno nadležnog suda koji će biti i mjesno nadležan (v. supra ad 4.2.3.), Vrhovni sud treba donijeti i odluku kojom će individualizirati taj sud.

Tužbu koja je priložena uz prijedlog treba odbaciti kao nedopuštenu ako prijedlog bude odbijen zato što je utvrđeno da ne postoji nadležnost hrvatskih sudova (arg. ex 16/2.). Ako, međutim, prijedlog bude odbijen zato što je utvrđeno da se na temelju pravila o mjesnoj nadležnosti može odrediti koji je od stvarno nadležnih sudova mjesno nadležan, tužbu priloženu uz takav prijedlog treba "kratkim putem" proslijediti stvarno nadležnom sudu za koji Vrhovni sud nađe da je mjesno nadležan, analogno kao kad nenadležni sud predmet koji mu je uslijed "očite” pogreške ustupljen kao nadležnom ustupa nadležnom sudu (arg. ex 22/1.).

O drugim odlukama koje bi Vrhovni sud mogao donijeti u povodu prijedloga za ordinaciju v. supra ad 4.3.5.2.

\subsubsection{Sadržaj i učinci odluka u povodu prijedloga za ordinaciju}

Budući da se odluka Vrhovnog suda u povodu prijedloga za ordinaciju ne može pobijati pravnim lijekovima (v. infra ad 4.3.6.), ona postaje pravomoćna momentom donošenja, dok se učinci njezine pravomoćnosti vežu uz moment s obzirom na koji se ocjenjivala osnovanost toga prijedloga.

Odluka kojom je odbijen prijedlog za ordinaciju zato što je utvrđeno da hrvatski sudovi nisu nadležni za suđenje u konkretnom sporu, deklarira to utvrđenje. Stoga treba odbaciti zbog nedostatka jurisdikcije tužbu koja se nakon toga podnese u tom sporu nekom sudu u Republici Hrvatskoj - svakako ako se kompetencijski relevantno činjenično stanje u međuvremenu bitno ne izmijeni. O odbacivanju tužbe koja je podnesena uz prijedlog u tom slučaju v. supra ad 3.3.5.4.

Prihvaćajući prijedlogu za ordinaciju i određujući koji će stvarno nadležni sud biti i mjesno nadležan, individualizirajući time taj sud kao stvarno i mjesno nadležan za suđenje u određenom sporu, Vrhovni sud ne ordinira samo mjesnu, već i stvarnu nadležnost toga suda, ali i deklarira i postojanje jurisdikcije hrvatskih sudova. Zato će i sudovi pred kojima će postupak u konkretnom pravnoj stvari biti pokrenut odnosno nastavljen nakon donošenja odluke o ordinaciji biti vezani za takvo određenje nadležnosti. U tom se postupku više ne može otvarati pitanje sudske nadležnosti, ali ni pitanje stvarne i mjesne nadležnosti ordiniranog suda, svakako osim ako zbog okolnosti koje nastupe nakon momenta na koji se odnosi pravomoćnost rješenja o ordinaciji ne dođe do promjena u tim nadležnostima. S jedne strane, to znači da su i sud i stranke u postupku pred ordiniranim sudom vezani za rješenje o ordinaciji u naznačenom smislu, dok se, s druge strane, i sud i stranke u postupku pokrenutom pred sudom čija nadležnost nije ordinirana, npr. podnošenjem tužbe tom sudu, mogu u skladu s općim pravilima o tome pozivati na njegovu stvarnu i mjesnu nenadležnost. 


\subsubsection{Pravni lijek}

Protiv odluke Vrhovnog suda o prijedlogu za ordinaciju žalba, ${ }^{102}$ ali ni drugi pravni lijekovi nisu dopušteni. Naime, iako to nije izrijekom propisano, protiv mogućnosti da se takva odluka Vrhovnog suda pobija pravnim lijekovima posredno bi govorila okolnost da uopće nije utvrđena (funkcionalna) nadležnost toga suda za odlučivanje o pravnim lijekovima protiv odluka koje bi donio, ali ni sastav u kojemu bi to činio (arg. ex 34.d/1., 44.). U prilog takvom stavu moglo bi se pozvati i na odredbu prema kojoj žalba nije dopuštena ni protiv odluka Vrhovnoga suda kad odlučuje o sukobu o nadležnosti (arg. a cohaerentia, a completudine, per analogiam ex 24/3.). Konačno, odluka o ordinaciji bila bi zapravo diskrecijski (u pogledu izbora mjesno nadležnog suda) nekontrolabilni akt najvišeg suda u državi, akt pri čijem bi se donošenju taj sud u bitnome rukovodio razlozima oportuniteta, ipak vodeći računa o interesima obiju stranaka te o pravno političkim zasadama od kojih polaze zakonska pravila o mjesnoj nadležnosti (v. supra ad 3.2.3.).

Navedeno rješenje ne bi bilo u protivnosti s Ustavom jer on jamči samo pravo na žalbu ili drugu pravnu zaštitu protiv pojedinačnih pravnih akata donesenih u postupku prvog stupanja pred sudom ili drugim ovlaštenim tijelom (18. URH), a u slučaju u kojemu Vrhovni sud ordinira riječ je o odluci koju donosi najviši sud u funkciji suda koji rješava jedno specifično kompetencijsko pitanje od važnosti za njemu podređene sudove.

Okolnost da protiv odluke u povodu prijedloga za ordinaciju nije dopušten pravni lijek, svakako, potencira značenje načela kontradiktornosti i otvorenog pravosuđenja i u ordinacijskom postupku (v. supra ad 4.3.4.).

Budući da bi se odlukom kojom se odbija prijedlog za ordinaciju zato što je utvrđeno da ne postoji jurisdikcija hrvatskih sudova moglo povrijediti pravo na sudsku zaštitu pred tim sudovima, u načelu bi protiv takve odluke bila dopuštena ustavna tužba. Ustavna bi tužba bila dopuštena i u slučaju u kojemu bi u ordinacijskom postupku bilo povrijeđeno pravo protivne stranke na pravičan postupak time što joj nije bila pružena mogućnost da sudjeluje u tom postupku. (Arg ex 62. UZUSRH) $)^{103}$ Ustavna tužba bila bi dopuštena i protiv odluke kojom bi bila utvrđena jurisdikcija hrvatskih sudova i ordinirana stvarna i mjesna nadležnost određenog suda jer bi se i takvom odlukom moglo dovesti u pitanje pravo stranke da joj ne sudi nenadležni sud.

\subsubsection{Postupak nakon donošenja odluke}

Postupanje Vrhovnog suda nakon što donese odluku o ordinaciji ovisi o tome bi li uz taj prijedlog bila priložena tužba. Ako tužba ne bi bila priložena, odluku o ordinaciji trebalo bi dostaviti objema strankama, a predlagatelj bi na temelju te odluke mogao podnijeti ordiniranom sudu, treba uzeti u odgovarajućem roku. Ako bi tužba bila priložena, odluku o ordinaciji zajedno s tužbom trebalo bi ustupiti ordiniranom sudu (v. supra ad 3.5.4.).

102 Tako i TRIVA-DIKA, op. cit., 284.

103 UZUSRH: Ustavni zakon o Ustavnom sudu Republike Hrvatske, NN proč. 99/99, 29/02, 49/02. 
Odluku kojom se odbacuje odnosno odbija prijedlog Vrhovni sud treba dostaviti strankama, iznimno samo predlagatelju ako je o prijedlogu odlučio prije nego što je protivniku omogućeno da se očituje. O postupanju u tim slučajevima s tužbom koja je bila podnesena uz prijedlog za ordinaciju v. supra ad 4.3.2.

Ako se prihvati stajalište da bi Vrhovni sud o prijedlogu za ordinaciju odlučivao ex parte, protivnoj bi se stranci moralo priznati pravo da u postupku pred ordiniranim sudom ističe prigovor nedostatka jurisdikcije (18.), stvarne (17.) i mjesne (20.) nenadležnosti. Ona bi svakako trebala imati pravo pozivati se i na sporazum o međunarodnoj ili mjesnoj nadležnosti (70.). Takva bi prava te stranke proizlazila iz njenog Ustavom impostiranog prava da o njezinim pravima (građanske naravi) odlučuje zakonom ustanovljeni neovisni i nepristrani sud u pravično provedenom postupku (29/1. URH). Ne bi se moglo smatrati da je pravično proveden postupak u kojemu bi o pravu stranke da joj sudi sud čija je nadležnost ustanovljena zakonom bilo odlučeno mimo nje.

U postupku nakon donošenja rješenja o ordinaciji obje bi stranke mogle isticati prigovore razne nenadležnosti pozivajući se na okolnosti koje su nastupile nakon momenta na koji bi se odnosila pravomoćnost toga rješenja - u onom smislu u kojemu te prigovore mogu isticati u postupku zbog okolnosti koje su nastale nakon podnošenja tužbe sudu (15.), praktično samo zbog razloga koji bi doveli do prestanka jurisdikcije hrvatskih sudova. Ta će mogućnost često u velikoj mjeri ovisiti o prijelaznom režimu propisa kojima je izmijenjena nadležnost suda koji vodi postupak.

\subsection{Problem naknadne ordinacije}

Prema važećem uređenju prvostupanjski sud u pravilu više ne pazi na svoju mjesnu nadležnost (arg. ex 20.). To praktično znači da tužitelj može po vlastitom izboru podnijeti tužbu bilo kojem stvarno nadležnom sudu, čija će se mjesna nadležnost naknadno zasnovati ako tuženik pravodobno ne istakne prigovor mjesne nenadležnosti (arg. ex 20.). Problem, pritom, može nastati u slučajevima u kojima je tuženik pravodobno i osnovano prigovorio da sud pred kojim je postupak pokrenut nije mjesno nadležan, ali u kojima sud pred kojim je postupak pokrenut ne može na temelju pravila o mjesnoj nadležnosti utvrditi koji je sud mjesno nadležan i ustupiti predmet tom sudu. Naime, sud koji se oglašava mjesno nenadležnim treba u rješenju kojim će to deklarirati odrediti i sud koji je tako nadležan (arg. ex 21., 22.). Budući da u zakonu nema izričitog rješenja za naznačenu situaciju, trebalo bi tu prazninu popuniti prihvaćanjem instituta naknadne ordinacije, otvaranjem mogućnosti da sud koji je utvrdio da nije mjesno nadležan predloži Vrhovnom sudu da ordinira sud koji će u konkretnom sporu biti mjesno nadležan i kojemu će nakon toga predmet biti ustupljen.

Naznačeni bi problem, eventualno, bilo moguće, vrlo nategnuto, prevladati i odgovarajućom kombinacijom instituta nužne i svrhovite delegacije. Naime, sud čija je nenadležnost $u$ određenom predmetu utvrđena ne može postupati u tom predmetu (uvjet za nužnu delegaciju - arg. ex 67.). Međutim, u takvom bi slučaju trebalo moći delegirati nadležnost onom od stvarno nadležnih sudova u državi kojemu bi ga bilo 
najsvrhovitije delegirati (pretpostavka za svrhovitu delegaciju - 68.).

Sud pred kojim je postupak pokrenut u sporovima u kojima je ovlašten ex officio paziti na svoju mjesnu nenadležnost i koji na temelju pravila o mjesnoj nadležnosti ne bi mogao utvrditi koji je sud mjesno nadležan da bi mu predmet ustupio, trebao bi također moći isprovocirati naknadnu ordinaciju odnosno delegaciju nadležnosti.

\subsection{Delegacija nakon ordinacije}

Ordinacija ne isključuje delegaciju - svrhovitu i nužnu. Vrhovni sud ordinacijom samo određuje koji će sud u određenom sporu biti ovlašten suditi s istim učinkom kao da je nadležnost tog suda utvrđena na temelju zakona. Stoga se nakon što određeni sud bude ordiniran kao stvarno i mjesno nadležan, nadležnost može delegirati na neki drugi sud po općim pravilima o nužnoj (67. v. ) i svrhovitoj (68., v.) delegaciji.

\section{ZAKLJUČNE NAPOMENE}

Instituti delegacije i ordinacije nadležnosti nakon Novele 2003. u osnovi odgovaraju potrebama prakse. Izmjenama instituta svrhovite delegacije u značajnoj je mjeri ograničena mogućnost dilatorne zloporabe toga instituta. De lege ferenda, bilo bi potrebno izrijekom odgovoriti na pitanja je li moguća i delegacija (nužna i svrhovita) "mjesne" nadležnosti drugostupanjskog suda, tko odlučuje, u kojem sastavu, o nužnoj delegaciji, podnosi li se tužba uz prijedlog za ordinaciju ili tek nakon nje, itd. Trebalo bi svakako razmisliti o mogućoj integraciji ili preciznijem funkcionalnom razgraničenju između nužne i svrhovite delegacije. Odgovori na neka od tih pitanja pokušali su se ponuditi u ovom radu. Pritom bi, svakako, trebalo uzeti u obzir i okolnost da je sukcesivnim izmjenama u uređenju instituta o kojima je riječ, osobito o ordinaciji nadležnosti u značajnoj mjeri smanjeno njihovo praktično značenje. 


\section{LITERATURA}

1. Ustavni zakon o Ustavnom sudu Republike Hrvatske, NN, proč. 99/99, 29/02, 49/02.

2. Zakon o radu, NN, 93/14.

3. Zakona o parničnom postupku, SL SFRJ, 4/77 - 35/91; NN 26/91, 53/91, 91/92, 12/99, 88/01, 117/03, 88/05, 84/08, 123/08-ispr., 57/11, 25/13, 28/13 - ZS i 89/14.

4. Zakonu o područjima i sjedištima sudova, NN 128/14.

5. Zakonu o područjima i sjedištima sudova, NN, 144/10, 84/11.

6. Zakonu o sudovima, NN, 28/13, 33/15, 82/15, 82/16.

7. DIKA, Građansko parnično pravo, Narodne novine, VII., § 31., 32.

8. KLAIĆ, Rječnik stranih riječi, 1990., 271., 272.; Rječnik hrvatskog jezika, Leksikografskog zavoda Miroslav Krleža i Školske Knjige, 2000., 166.

9. TRIVA-DIKA, Građansko parnično procesno pravo, Narodne novine, 7. izd., 2004., 271.

10. VSRH: Gr1-207/04 - IO 1/04-262.

11. VSH: R-112/88 - PSP 40/90.

12. VSRH: Gr1-75/13-2 od 24. travnja 2013.

13. VSRH: R-63/87 - PSP 35/151.

14. VSRH: Grl-121/2007 - INF-N 5655/07.

15. VSRH: Grl: 745/2012-2 - INF-br. 6290-6291/2014.

16. VSRH: Gr-272/00 - IO 1/01-163.

17. VSRH: Gr-13501 - IO 1/02-184.

18. VSRH: Gr-1-573/02 - INF-N 5204-5205/04.

19. VSH: R-329/78 - NZp 11/79-76., VSRH: Gr-133/\&01 - INF br. 5032-5033/2002.

20. VSRH: Gr-133/01 - INF br. 5032-5033/2002.

21. VPSH: Rp-87/80 - PPP 7/84-63.

22. VSH: Gr-218/89 - PSP 46/90.

23. VSH: R-117/81 - NZp 19/82-134.

24. VSRH: Gr1-241/08 2.7.08 - INF-N 5701/08.

25. VSH: R-147/79 - NZp 16/80-63.

26. VSH: R-274/78 - NZp 14/79-76.

27. VSH:R 356/83 - NZp 25/85-125.

28. VSH: R-100/83 - PSP 23/246.

29. VSH: R-172/83 - NZp 23/84-160.

30. VSH: R-174/84 - NZp 26/85-110.

31. VSH: R-380/84 - NZp 27/85-101.

32. VSH: R-329/85 - NZp 27/85-101.

33. VSH: R-51/87 - PSP 35/150.

34. VSH: Gr-218/89 - PSP 46/90.

35. VSRH: Gr-476/97 - INF 4680/99.

36. VSRH: Gr-24/99 - INF-N 4873/00.

37. VSRH: Gr-288/00 od 20.6.2000.

38. VSRH: Gr-584/00 - INF-N 4960-4961/01.

39. VSRH: Gr-565/00 - INF-N 5010/02.

40. VSRH: Gr-967/00 - INF-N 5016-5017/02.

41. VSRH: Gr- 353/01 - INF-N 5023/02.

42. VSRH: Gr-511/01 - INF-N $5028 / 02$.

43. VSRH: Gr-974/03 - INF-N 5307/05.

44. VSH: R-42/83 - SP 6/84-50.

45. VSH: R-275/83 - NZp 24/84-129.

46. VSH: R-155/83 - NZp 23/84-161.

47. VSH: R-288/84 - SP 12/85-53. 
48. VSRH: Gr-216/93 - IO 1994/282.

49. VSRH: Gr-143/93 - IO 1994/281.

50. VSRH: Gr-408/93 - IO 2/1995-120.

51. VSRH: Gr-184/98 - INF-N 4868-4869/00.

52. VSRH: Gr-261/98 - INF-N 4825/00.

53. VSRH: Gr-103/99 - INF-N 4876-4877/00.

54. VSRH: Gr-256/00 od 27. 6. 2000.

55. VSRH: Gr-282/00 - INF 4925/01.

56. VSRH: Gr-2/00 - INF-N 4962-4963/01.

57. VSRH: Gr1-576/02 - INF-N 5190/03.

58. VSRH: Gr1-613/02 - INF-N 5182.

59. VSRH: Gr1-94/15-2 od 3. ožujka 2015.

60. VSH: R-174/72 - NZp 2/73-29.

61. VSRH: Gr-266/00 - INF N 4939/01.

62. VSRH: Gr-1034/01 - INF-N 5179/03.

63. VSRH: Gr-133/04 - INF-N-5287/04.

64. VSRH: Gr-497/97 -INF.N 4899/01.

65. VSH: Gr-1/89, R-362/88 - PSP 41/92.

66. VSRH: Gr-1-262/02 - INF-N 5106/03.

67. VSRH: Gr-316/97 - INF-N 5076-5077/02.

68. VSRH: Gr. Broj: Gr1 383/08-2 od 18. prosinca 2008.

69. VSRH: Gr1 382/08-2 od 27. studenoga 2008.

70. VSRH: Broj: Gr1-127/12-2 od 29. ožujka 2012. 


\section{Mihajlo Dika*}

Summary

\section{DETERMINATION OF JURISDICTION BY A HIGHER COURT IN CIVIL PROCEEDINGS}

The paper analyses three legal terms which regulate the determination of jurisdiction by a higher court in civil proceedings: necessary delegation of jurisdiction, purposeful delegation of jurisdiction and ordination of jurisdiction. An attempt is made to determine the meaning of these terms as well as their prerequisites and their legal effects. The paper also points to the potential functional interference between these concepts and thus suggests that there is a need to delimit the scope of their application. Special emphasis is also given to the influence of relatively new changes in the field of organisation and jurisdiction of courts upon the practical application of those concepts.

Keywords: territorial jurisdiction, necessary delegation of territorial jurisdiction, purposeful delegation of territorial jurisdiction, ordination of territorial jurisdiction.

\section{Zussamenfassung}

\section{BESTIMMUNG ÖRTLICHER ZUSTÄNDIGKEIT IM ZIVILPROZESS DURCH DAS IM RECHTSZUG ZUNÄCHST HÖHERE GERICHT}

Die Arbeit bespricht drei Rechtsinstitute, welche die Bestimmung örtlicher Zuständigkeit im Zivilprozess durch das im Rechtszug zunächst höhere Gericht regulieren: das Institut der sog. notwendigen Delegation der Zuständigkeit, das Institut der sog. zweckmäßigen Delegation der Zuständigkeit und das Institut der sog. Ordination der Zuständigkeit. Bei der Besprechung genannter Institute versucht man, diese Begriffe, ihre Voraussetzungen und Rechtsfolgen zu bestimmen. Man weist auch auf potentielle funktionale Interferenz zwischen diesen Begriffen und auf die Notwendigkeit der Einschränkung ihrer Anwendung hin. Besonderen Wert legt man in der Arbeit auf den Einfluss neuester Änderungen im Bereich der Gerichtsverfassung und Gerichtszuständigkeiten auf die Anwendung dieser Rechtsinstitute in der Praxis.

Schlüsselwörter: örtliche Zuständigkeit, notwendige Delegation örtlicher

Zuständigkeit, zweckmäßige Delegation örtlicher

Zuständigkeit, Ordination örtlicher Zuständigkeit.

* Mihajlo Dika, Ph. D., Professor Emeritus, Faculty of Law, University of Zagreb. 
Riassunto

\section{LA DETERMINAZIONE DELLA COMPETENZA TERRITORIALE DA PARTE DELLE CORTI SUPERIORI NEL PROCEDIMENTO CIVILE IN SINGOLE MATERIE}

L'oggetto del presente lavoro è costituito da tre istituti mediante i quali si disciplina la determinazione della competenza territoriale da parte delle corti superiori nel procedimento civile in singole materie: l'istituto della c.d. delegazione necessaria di competenza; l'istituto della c.d. delegazione funzionale di competenza e l'istituto del c.d. ordine di competenza. In occasione dell'analisi di ciascuno di questi istituti si tenta di determinare la loro nozione, i loro presupposti e gli effetti giuridici della loro applicazione. Si cerca di segnalare la possibilità della loro interferenza funzionale, come anche la necessità della loro distinzione nell'applicazione. Viene particolarmente sottolineata l'influenza degli interventi relativamente recenti nella disciplina dell'organizzazione delle corti e della loro competenza rispetto alla loro portata.

Parole chiave: competenza territoriale, l'istituto della delegazione necessaria di competenza, istituto della delegazione funzionale di competenza, istituto dell'ordine della competenza territoriale. 
